\title{
The Effects of Means-tested Noncontributory Pensions on Poverty and Well-being: Evidence from the Chilean Pension Reforms
}

\author{
Italo López García and Andrés Otero
}

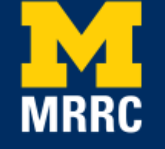

Project \#: UM16-18 


\title{
The Effects of Means-tested Noncontributory Pensions on Poverty and Well-being: Evidence from the Chilean Pension Reforms
}

\author{
Italo López García \\ RAND Corporation \\ Andrés Otero \\ Chilean Pension Regulator \\ February 2017 \\ Michigan Retirement Research Center \\ University of Michigan \\ P.O. Box 1248 \\ Ann Arbor, MI 48104 \\ www.mrrc.isr.umich.edu
}

(734) 615-0422

\section{Acknowledgements}

The research reported herein was performed pursuant to a grant from the U.S. Social Security Administration (SSA) funded as part of the Retirement Research Consortium through the University of Michigan Retirement Research Center Award RRC08098401. The opinions and conclusions expressed are solely those of the author(s) and do not represent the opinions or policy of SSA or any agency of the federal government. Neither the United States government nor any agency thereof, nor any of their employees, makes any warranty, express or implied, or assumes any legal liability or responsibility for the accuracy, completeness, or usefulness of the contents of this report. Reference herein to any specific commercial product, process or service by trade name, trademark, manufacturer, or otherwise does not necessarily constitute or imply endorsement, recommendation or favoring by the United States government or any agency thereof.

\section{Regents of the University of Michigan}

Michael J. Behm, Grand Blanc; Mark J. Bernstein, Ann Arbor; Shauna Ryder Diggs, Grosse Pointe; Denise Ilitch, Bingham Farms; Andrea Fischer Newman, Ann Arbor; Andrew C. Richner, Grosse Pointe Park; Ron Weiser, Ann Arbor; Katherine E. White, Ann Arbor; Mark S. Schlissel, ex officio 


\title{
The Effects of Means-tested Noncontributory Pensions on Poverty and Well-being: Evidence from the Chilean Pension Reforms
}

\begin{abstract}
Chile initiated in 1981 a privately managed, individual-account pension system that inspired similar reforms in many Latin American countries, and that has been considered as a possible model for Social Security in the United States. After 30 years in place, the Chilean pension system has been criticized for replicating existing inequalities in labor markets and increasing the risk of old-age poverty; for achieving lower levels of coverage; and for providing low pension benefits. Aiming at guaranteeing a minimum level of consumption upon retirement and increasing the incentives to contribute, in 2008 Chile reformed the Pension System, widening the welfare tier and improving the contributory tier through a means-testing scheme. This paper examines the impact of the 2008 Chilean pension on labor supply and well-being, using a version of the difference-in-difference estimator that assesses the effects of the reform through exogenous changes in pension wealth. Using longitudinal data from 2006 through 2012, and a sample of individuals that were not retired by the time of the implementation of the reforms, our preliminary estimates suggest that the pension reforms induced an increase in the probability of working formally, but at least among females, they reduced labor market participation. However, we find limited impacts of the reform on nonlabor outcomes. Besides some improvements in aggregate household expenditures and in measures of subjective well-being measures among males, we do not detect robust changes in health and well-being among individuals near retirement.
\end{abstract}

\section{Citation}

Lopez Garcia, Italo, and Andrés Otero. 2017. “The Effects of Means-tested Non-contributory Pensions on Poverty and Well-being: Evidence from the Chilean Pension Reforms.” Ann Arbor, MI. University of Michigan Retirement Research Center (MRRC) Working Paper, WP 2017358. http://www.mrrc.isr.umich.edu/publications/papers/pdf/wp358.pdf

\section{Authors' acknowledgements}

We thank the financial support from the Michigan Retirement Research Center for making this research possible (grant reference UM16-18), and we thank the Chilean Pension Regulator for their technical support regarding the use of administrative records on pensions. 


\section{Introduction}

Over the last three decades, many developing countries have started replacing traditional pay-as-you-go pension systems by Defined Contributory pension systems to overcome issues like securing long-term funding of the pension system and to increase coverage. The model has been lauded as a possible model for Social Security overhauls in high income countries like the United States. However, contributory pensions have proved to be difficult to fully scale up in developing economies with large informal labor markets (Dethier et al. (2010)), leaving large segments of the population uncovered. As a result, the introduction of means-tested non-contributory pension schemes as a welfare pillar complementing contributory pensions has become increasingly common in countries that struggle to reduce poverty among the elderly. The prevalence of old-age poverty has also been a motivating issue for national pension reform in the United States, where poverty rates for certain subgroups of the population like single males and single females are above $16 \%$.

In this paper, we study the effects on economic security, mental health and well-being of major reform introducing means-tested non-contributory pensions in the Chilean pension system. Chile initiated in 1981 a privately managed individual-account pension system that inspired similar reforms in many Latin American countries. Despite its success in securing long-term funding, after more than 30 years in place the system has been criticized for achieving low density of contributions, reduced coverage, and very low pension benefits, particularly because of low levels of attachment to labor markets among low-income individuals and females (de Mesa et al. (2006), Behrman et al. (2011), Kay and Kritzer (2001)). Accordingly, in 2008 Chile implemented a new set of reforms seeking to guarantee a minimum level of consumption upon retirement, prevent old-age poverty and reduce gender inequalities. Targeted to individuals 65 years old or older living in households in the bottom $60 \%$ of the income distribution, the reform included a non-contributory welfare pension (the Pension Basica Solidaria, PBS) of US\$125/month, and a supplemental top-up (the Aporte Previsional Solidario, APS) for individuals with a low self-financed pension, which was phased-out as the private pension increased. Additional welfare measures targeted to reduce gender inequalities included bonuses for each child born, compensations upon divorce, and the implementation of survivorship pensions. For a comprehensive evaluation of the reform impacts we merge administrative records on pensions and contributions to the Social Protection Survey (Encuesta de Proteccion Social, EPS) a nation-wide longitudinal survey containing a rich set of information about Chilean households including labor market participation, incomes, expenditures in health and basic goods, assets and savings, and physical and mental health. It was initiated in 2002 and followed-up in years 2004, 2006, 2009 and 2012.

To investigate the effects of the reform on the outcomes of interest incorporating these mechanisms we adopt a version of the difference in differences estimator first proposed by Attanasio and Rohwedder (2003) and Attanasio and Brugiavini (2003) in studying the effects of pension reforms in the UK and Italy, respectively. Under this approach, we estimate the behavioral responses in labor supply, consumption, income and well being outcomes respect to changes in expected pension wealth and accrual rates for individuals at different points in the life cycle. In particular, we study separately individuals facing retirement from those already retired. The adoption of such a methodology has some challenges. First, we need rich data of expected pension wealth across individuals and over time. We rely on rich monthly administrative records provided by the Chilean Pension Supervisor on pension wealth, contributions and pension benefits available for the entire period of study. Second, we need to construct measures of expected pension wealth at time $t$ for each individual upon retirement. In a DC pension system this is problematic because the reform changes the incentives to participate in the formal sector and therefore 
to contribute. To estimate the expected pension wealth, we adopt the approach used by Attanasio et al. (2014), who forecast future contributions and wage profiles using the history of labor supply and contributions for each individual and then compute the present value of pension wealth at every point in time for each individual using well-known formulas. Finally, expected pension wealth and accrual rates are likely to be endogenous because contributions can be correlated to unobserved heterogeneity in preferences for labor supply and consumption. Our identification strategy relies on instrumenting expected pension wealth and accrual rates with interactions of group dummies and year dummies reflecting the differential impact of the reform across different segments of the population.

The evidence on the impacts of non-contributory pensions schemes in economic security, poverty reduction and well being is very limited. In the United States, the SSI has remained largely unchanged since 1974. Hubbard et al. (1994) were the first to highlight the theoretical reasons for why means-tested pensions discourage savings among households with low-income. Since then, several authors have confirmed their insights (Neumark and Powers (1998); Ziliak (2003)) and extended it to find support for reducing labor supply of individuals approaching age eligibility (Neumark and Powers (2000)). However, these studies have relied on variation by state to identify parameter estimates, since policy experiments have been limited in scope. The evidence in the developing world is more suggestive. Case and Deaton (1998) study the non-contributory pension system in South Africa and find substantial improvements in mental health and consumption expenditures. Duflo (2000) extended this analysis and finds that higher pension benefits also improved health outcomes for children living with grandparents. In a recent work, Galiani et al. (2014) exploited the natural experiment provided by the cash transfer scheme Mexico's Adultos Mayores Program (Older Adults Program), finding that this substantially improved mental health and consumption, reduced income inequality and decreased labor supply.

Previous papers have studied the 2008 Chilean reform. Attanasio et al. (2014) find evidence that the reform reduced income inequality, but participation in formal labor markets was reduced. Using a structural approach,Joubert (2015) finds that the Chilean mandatory pension scheme encourages labor informality and that the system could lower minimum pension spending while guaranteeing the same income for retirees. However, these papers have mostly focused on labor market outcomes and pension incomes, and the effects of the reform on alternative measures of well-being (such as expenditures and mental health) have not been addressed. In this paper, we evaluate the effects of the reform in poverty reduction and economic security among older adults and whether this translates into higher consumption levels, health expenditures, physical and mental health. Mental Health has been well-accepted as a critical measure of quality of life among the elderly (Campbell et al. (1976), Walker (2005)). In this regard, our paper is close to the work of Finkelstein et al. (2011), who find that expansions of Medicaid during the 90's increased mental health among the poor elderly in the United States.

Based on a sample of individuals that were still not retired by the time of the implementation of the reform, our preliminary estimates suggest a reduction in labor market participation product of a negative income effect, but conditional on work, an increase in the probability of work formally, product of a positive substitution effect resulted from higher accrual rates. Among other outcomes, we observe significant increases in some relevant aggregate household expenditures, in medical expenditures among females, and an improvement in subjective well being measures among males. Section 2 of this paper describes the set of reforms implemented in 2008; Section 3 describes our empirical strategy; Section 4 describes the data; Section 5 provides an extensive revision of the data stylized facts; Section 6 reports our preliminary results; and Section 7 concludes. 


\section{The Chilean Pension Reforms}

Chile has a fully funded defined contributory pension system operating since 1981 . The core of the system is a mandatory contributory pillar under which workers employed formally (defined as those contributing to the private pension system) make monthly contributions of $10 \%$ that are saved into individual accounts. The individual accounts are privately managed by a pension fund administrator (PFA), chosen by the worker, which invests the funds in the national and international financial market. PFAs charge an additional variable fee of $2 \%$, used to cover administration costs. Contributions are voluntary for the self-employed. As a consequence, the large majority of self-employed workers are in the informal sector. Social security contributions are compulsory for employees, and employers are responsible for deducting them automatically from salaries. Small firms, however, can easily avoid such rules. As a result, roughly half of the informal workers are salaried employees and the other half are self-employed (Lopez-Garcia (2014)). At the legal age of retirement, 65 for men and 60 for women, individuals can withdraw from the labor force and start to receive a pension. Therefore, the level of pension benefits depends primarily on the contributions saved in individual accounts during the life cycle, and on the return to those savings. Workers with low frequency of contributions do not accumulate enough pension wealth leading to low pension benefits and welfare upon retirement. Moreover, as contributions accrue returns over the life cycle, contributions made during the initial periods of the cycle bear have a higher impact in pension benefits than those made near retirement. Consequently, individuals that do not participate in the pension system in young adulthood, such as women in their reproductive years or individuals subject to a high volatility of employment, are more likely to face old age poverty.

In addition to the contributory scheme, before 2008 the Chilean pension system included a welfare pillar compounded by two elements. First, a contributory minimum pension, or Pension Minima Garantizada (PMG). To be eligible for the PMG, the individual should have contributed to the pension system's second tier for at least 240 months and should not be able to self-finance the PMG with her accumulated pension contributions. In 2008, the PMG was Ch\$ 96,390 (US\$212). Second, the means-tested Pension Asistencial (PASIS), allocated to retirees belonging to the poorest quantile of a poverty indicator constructed from data on income and wealth from a common survey instrument used for the allocation of all welfare subsidies (Ficha de Proteccion Social, or FPS). In 2008, the PASIS was Ch\$ 54,091 (US\$ 119) a month, funded by the government out of general tax revenues.

After more than 30 years of operation, the Chilean privately managed pension system has been heavily criticized for delivering pension benefits much lower than initially promised. One clear indicator of this statement is the system's low level of replacement rates: In 2005, they were $28 \%$ for women and $51 \%$ for men in 2005, percentages that are even lower for individuals of lower SES ${ }^{1}$. The main reason behind these ex-post low-average replacement rates is that certain groups of the population, do not contribute frequently enough to the system. This is particularly true in the case of individuals with low attachment to labor markets, such as women or individuals with low education. For example, the average frequency of contributions has been $42 \%$ for women and $61 \%$ for men. For women, $44 \%$ of the non-contributed periods correspond to periods of inactivity, consistent with low levels of female labor participation in comparison with OECD countries. Because of low levels of attachment to the formal labor markets, most individuals were not able to fulfill the contribution requirement and obtain the PMG. Moreover, eligibility rules to obtain the PASIS were too restrictive and only a very small fraction of retirees were eligible for this very low subsidy.

\footnotetext{
${ }^{1}$ Informe Final, Comision Reforma Previsional. El derecho a una vida digna en vejez. Hacia un contrato social con la prevision de Chile. http://www.consejoreformaprevisional.cl/view/presentacion.asp, 2006.
} 


\section{Pre and Post Reform First Tier}

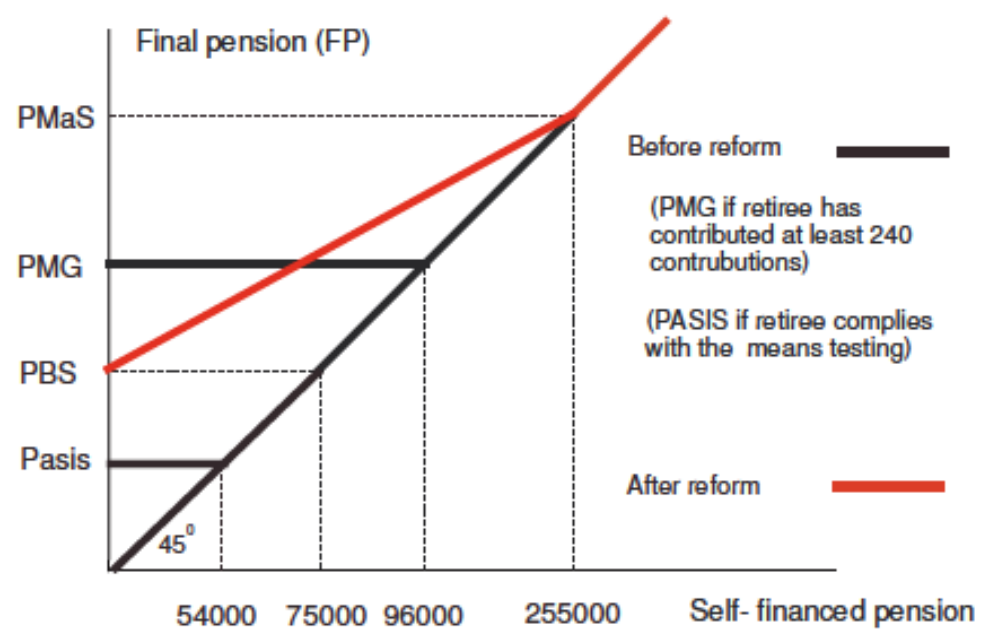

Figure 1: The Chilean Pension Reforms in 2008

In 2008, a major pension reform was implemented to tackle the main problems of the pension system, specially those related with low frequency of contributions. First, two new components were introduced in the welfare tier: i) a non-contributory welfare pension (PBS hereafter) set at US\$ 132 in 2008 and increased to US\$ 165 from 2009. This benefit intended to alleviate poverty for those retirees older than 65 years old by replacing the old second-pillar benefits (PMG or PASIS), and expanding the eligibility to the poorest $60 \%$ of the population; and ii) a welfare pension complement (APS hereafter), intended to sustain consumption by topping-up the self-funded contributory pension for an amount between the flat non-contributory PBS and a maximum funded pension (PMAS), increased gradually the final pension benefit until it reaches the value of US\$ 561. Therefore, the APS is decreasing in the funded pension. Second, different benefits targeted at different sub-groups were added to recognize the disadvantages generated by the structure of the system, in particular to women. These new elements included a children subsidy obtained by every mother, a compensation upon divorce, a male survivor pensions and genderdependent survival pension premium rates.

The pre- and post-reform schemes are shown in Figure 1. The 45-degree line represents the pure DC system in which self-saved pension wealth (horizontal axis) becomes a final pension (vertical axis) upon retirement. Before reform, the two black at lines represent either the means-tested PASIS or the contributory PMG pension. After the reform, the red line shows the minimum non-contributory pension, PBS, which is topped-up by the APS subsidy. In this sense, the reform sets up a more comprehensive system in which the redistributive and the mandatory tiers of the system are integrated with each other. The reform costs annually around $1.1 \%$ of $\mathrm{GDP}^{2}$, being one the largest of the Chilean social reforms in recent years.

The changes introduced by the reform illustrated in Figure 1 affected different groups in different ways. Before the reform, retirees at the bottom of the pension distribution could be divided into three groups: (i) those who received their funded pension (the 45-degree line in Figure 1), (ii) those who received the PMG (at least 240 months of self-financed contributions), and (iii) those who received the PASIS

\footnotetext{
${ }^{2}$ According to forecasts by the Chilean Pension Regulator, Superintendencia de Pensiones (SPE), and the Budget Office, Direccion de Presupuesto (DIPRES).
} 
pension. After the reform, retirees receiving the PASIS (group iii) now receive the PBS so there is a clear increase in welfare for them. Those receiving a self-financed pension lower than the PMG (group i) are now receiving a higher level of pension, determined by the PBS. And of those receiving the PMG before the reform (group ii), some will receive a higher and some a lower final pension benefit.

The changes introduced to the welfare pensions depicted in Figure 1 change substantially accrual rates and accumulated pension wealth, in turn changing expectations about pension benefits upon retirement. The reform induces changes to accrual rates and expected pension wealth that differ across individuals depending on their self-funded pension wealth by the time of the reform. For example, an individual receiving the PMG before the reform goes from a zero-accrual rate over a large region of her contributions to a positive accrual rate, represented by the slope of the red line in Figure 1. An individual who was on the 45-degree line to the left of 255,000 but to the right of 75,000 now receives the PBS and will have a lower accrual rate relative to the pre-reform situation. These changes can trigger different behavioral responses in terms of labor supply, consumption and savings for retirement, which in turn reinforce endogenously the future accumulated pension wealth and pension benefits among retirees. Therefore, a comprehensive evaluation of the reforms in labor supply, consumption, poverty and other welfare indicators upon retirement (such as mental health), require to take into account these dynamic incentives. In particular, the reform would have differential effects in different groups of individuals depending on their self-financed pension wealth by the time of the reform, on their position in the life-cycle, and on whether they are eligible for further targeted subsidies such as those available for women.

\section{Methods}

The 2008 Chilean pension reform introduced important changes to both the welfare and the contributory pillar in place before 2008 that in turn changed completely the incentives to contribute to the pension system and participate in the labor market. The new incentives were specifically focused on particular sub-groups of the population. In order to evaluate the effect of the reform on labor supply, consumption and other outcomes we exploit how these different groups react to changes in the pension scheme. Workers contribute to the pension system, accumulating pension wealth into individual accounts to self-finance future pensions upon retirement. Therefore, individuals accrue pension wealth each period according to their contributions based on wages and to the associated returns for those contributions. This accrual mechanism, combined with the welfare elements of the system, generates particular incentives to contribute to the system. Importantly, the pension reform changes the expected pension at retirement and the accrual rate through both the new welfare tier in place and through the various mechanisms introduced to complement the contributory tier.

In practice, we want to estimate the behavioral responses in labor supply, consumption, income and well being outcomes respect to changes in expected pension wealth and accrual rates for individuals at different points in the life cycle ${ }^{3}$. Following Attanasio and Rohwedder (2003) and Attanasio and Brugiavini (2003) we estimate the following outcome equation for a series of outcomes denoted by $Y_{i t}$ :

$$
Y_{i t}=X_{i t} \gamma+\beta E_{t} P W_{i}+\delta E_{t} A R_{i}+\lambda_{t}+\alpha_{i}+\varepsilon_{i t}
$$

\footnotetext{
${ }^{3}$ In this version of the paper we merge individuals facing retirement with those already retired. The estimation by different groups is work in progress.
} 
In this specification, $E_{t} P W_{i R}$ is the expected accumulated pension wealth at time $t$ upon retirement, $E_{t} A R_{i}$ is the expected accrual rate at retirement as a consequence of working formally at time $t, X_{i t}$ is a vector of household sociodemographic characteristics, and $\lambda_{t}$ and $\alpha_{i}$ are time and individual fixed effects, respectively. The set of outcomes $Y_{i t}$ include labor status, household income (in levels and the distribution), poverty, expenditures in basic goods and medical expenditures, self-care variables, physical health, as well as subjective well-being. The 2008 pension reforms are likely to change expectations about pension benefits in the future through changes in pension wealth and accrual rates, so the parameters of interest are $\beta$ and $\delta$.

Standard life-cycle models would predict that estimating Equation (1) with standard OLS methods will yield inconsistent estimates of the parameters of interest. Both the expected pension wealth and accrual rates are likely to be correlated with individual time-invariant preferences for labor supply and consumption $\left(\alpha_{i}\right)$, and with with time-variant unobserved factors that are likely to affect the decision to work and the decision to work formally conditional on working, which in turn jointly determine outcome variables and the accumulation of pension wealth. To overcome this problem, we will instrument with time dummies interacted with group dummies, which will be defined to capture systematic differences in pension wealth and accrual rate triggered by the reforms. For identification, our key assumption is that the overall trends in the outcome variables of the different groups are the same, once the outcomes have been scaled appropriately. The different groups used to identify the first stage are determined by the reform's eligibility conditions, such as being poor, age or female, which will allow us to define groups for whom there might be changes in the expected self-financed pension wealth at retirement, as well as in accrual rates. We will use the interaction of group dummies with time dummies as instruments for EPW and EAR in equation (1), which will enable controlling for unobserved heterogeneity. In order to include potential non-linear effects of unobserved heterogeneity influencing the endogenous variables and outcomes, we adopt a Control Function Approach, so in the first stage we regress Expected Pension wealth against the the interaction of time variables and group dummies, and polynomials of the predicted residuals of such a regression are included as covariates in the outcome equation.

It is important to notice that the inclusion of expected accrual rates makes sense only in the case of labor market outcomes, because of the direct link existing between participation in formal labor markets and the rate at which pension wealth increases. However, outcomes such as expenditures, health and well being, are not directly associated to accrual rates. In those cases, we will only expected pension wealth as the relevant endogenous variable.

An important limitation of the methodology proposed is that for the computation of expected pension wealth and accrual rates for each individual at any point in time, we need the complete life cycle history about labor market participation and pension system participation. Past history is observed in monthly administrative records about pension wealth and contributions administrated by the Chilean Pension Supervisor. However, future participation in the pension system and contributions based on incomes must be forecasted. We do so estimating a four system equation that jointly determine labor force participation, the decision to contribute if the individual works, and labor earnings if the person contributes (formal) and if she does not contribute (informal). Our procedure corrects for selection bias by the joint estimation of earnings equations and participation, and by explicitly including unobserved heterogeneity in the form of discrete and finite unobserved types, following Heckman and Singer (1984).

To forecast future labor market participation we use the Social Protection Survey (Encuesta de Proteccion Social, EPS), a nationwide longitudinal survey containing a rich set of information about Chilean households, including labor market participation, incomes, and rich socio-demographic variables such 
as education, number of children, sex, marital status, geographic zones, year, and economic sector. Importantly, the survey can be merged to administrative records where we retrieve the full history of contributions and labor market participation to complete the life-cycle profiles of our endogenous variables. At each period $t$ individual $i$ decides to work $\left(H_{i t}=1\right)$ or not to work $\left(H_{i t}=0\right)$. Workers that work can choose between to do it formally $\left(F_{i t}=1\right)$ or informally $\left(F_{i t}=0\right)$, where formality is defined as the decision to contribute to the pension system. Based upon working, individuals receive after tax wages

$w_{i t}^{F=1}$ and $w_{i t}^{F=0}$, respectively. We estimate the following 4 equation system by maximum likelihood:

$$
\begin{aligned}
H_{i t} & =1\left[H_{i t}^{*}=\gamma_{1} X_{i t}+\gamma_{2} Z_{i t}+\gamma_{3} Q_{i t}+\eta_{i}+\xi_{i t}\right. \\
F_{i t} & =1\left[F_{i t}^{*}=\gamma_{4} Z_{i t}+\gamma_{5} Q_{i t}+\alpha_{1} \eta_{i}+\varepsilon_{i t}>0\right] \\
\ln \left(w_{i t}^{F=1}\right) & =\gamma_{6} Q_{i t}+\alpha_{2} \eta_{i}+v_{i t}^{F=1} \\
\ln \left(w_{i t}^{F=0}\right) & =\gamma_{7} Q_{i t}+\alpha_{2} \eta_{i}+v_{i t}^{F=0}
\end{aligned}
$$

Where $Q_{i t}$ is a vector including age, gender, educational dummies, cohort dummies and year dummies, $Z_{i t}$ adds to the vector $Q_{i t}$ exclusion restrictions potentially determining the contribution decision such as the marital status and the number of children by age; and $X_{i t}$ incorporates the all previous variables additional exclusion restrictions such as the interaction between the number of children and gender. The error terms in participation equations $\xi_{i t}$ and $\varepsilon_{i t}$ are distributed $N(0,1)$, and the error terms in the wage equations are iid shocks distributed according to a $N(\mu, \sigma)$. Finally, $\eta_{i}$ is a common unobservable heterogeneity normally distributed, that allows the estimation process to control for different preferences across the population. We estimate the system by maximum likelihood methods using two points on the domain of $\eta$, which are estimated jointly with their associated probabilities.

\section{The Data}

The Social Protection Survey (Encuesta de Proteccion Social, EPS) is a nation-wide longitudinal survey containing a rich set of information about Chilean households, including labor market participation, incomes, expenditures in health and basic goods, assets and savings, and detailed measures of physical and mental health. It was initiated in 2002 and followed-up in years 2004, 2006, 2009 and 2012, providing extensive data pre- and post reform that can be linked to administrative records of pensions and contributions. We use the EPS for two purposes. First, to include regressors such as education, number of children, sex, marital status, geographic zones, year, and economic sector in the estimation of labor supply, contributions and earnings profiles used to forecast Expected Pension Wealth and Accrual rates at every point in time. Second, the EPS contains information about relevant outcomes that can be affected by the reforms, measured before and after such reforms occurred. We focus on the main groups of outcomes: Economic security, poverty rates and well-being.

In order to evaluate the effects of increased pension wealth in outcomes due to the reforms, the EPS survey is linked to rich monthly administrative data administered by the Chilean Pension Regulator on 
contributions, accumulated pension wealth and benefits patterns available for the entire population that has ever contributed to the system. This complete history, containing earnings and returns, allow us to compute the current accumulated pension wealth and accrual rates for each individual at each point in the past. In addition, we have merged the EPS data with administrative information on benefits of the non-contributive tier that these individuals received as a consequence of the reforms in order to verify our computations of expected pension benefits upon retirement after the reforms.

The main outcomes analyzed in this paper can be classified in six categories: Labor status and household income, aggregate expenditure in basic goods, physical health, self-care, use and expenditure in medical services, and subjective well-being.

Household total and per capita income: in addition to labor earnings from the primary job, household income includes several additional income measures such as additional perks, income form a second parallel job, pension benefits such as retirement, widower benefits and disability aid, incomes from rents, transfers from individuals outside the household (other relatives, friends), and other unclassified incomes such as deposit interests, sales of self-made products, etc. All these incomes were transformed into monthly earnings and were corrected by inflation.

Labor status: the EPS contains specific questions regarding the labor history of each interviewed individual. The module includes very detailed information about the individual's employment status between the current and the past survey wave, the salary, job duration, hours of work and other related variables. We use employment status to identify whether the individual is active in the labor force and, if so, whether she is working or unemployed, and the salary received for this work over the last 12 months.

Aggregate expenditure in basic goods: Individuals are asked about the total monthly expenditures in food, clothing, utilities (water, electricity, gas, etc.), transport and domestic help. We use this information to compute the proportion of each type of expenditure on household spending.

Self-care variables: Targeted at measuring behavioral outcomes, the survey asks whether the individual practices a sport at least once a week (seven categories that range from every day to never), whether she smokes and how much, and current consumption of alcohol. Three different types of alcohol beverages are asked, and we construct a binary index based on whether the person consumes regularly at least one of these three beverages.

Physical health: We compute the Index Body Mass (IBM ) for each individual based on information on self-reported weight and height. The EPS also ask for whether the respondent has been diagnosed with any of six serious/chronic illnesses such as respiratory problems, diabetes, depression, high blood pressure, cardiac problems or arthritis during the last two years. Responses were used to Variables calculated the prevalence of each of these illnesses in the population.

Use and expenditure on medical services: The survey asks for questions such as whether the respondent has been diagnosed of any disease, whether she is currently under treatment or not, and the reason why she is not currently under treatment. With these variables we construct an indicator of whether the respondent is "not being under treatment but needs it" that takes value 1 if the respondent was diagnosed a certain illness, is not under treatment and reports any reason other than "treatment not necessary" to why she is not receiving treatment. Other variables include the number of medical visits and out of pocket medical expenditures. 
Subjective well-being: This group includes questions related to self-perception of health, difficulties to perform daily activities, and a shortened version of the CESD scale to detect depression. Regarding selfperception of health, respondents declare own health in six categories that were recoded into two groups: good health (three categories: excellent, very good and good), and bad health (three left categories: regular, bad, very bad). A set of seven daily activities were asked and the difficulties that respondents had to perform them on a daily basis. Three indicators were constructed with these variables: difficulties to perform at least one of the seven daily activities, difficulties to perform at least one of four most basic activities including bathing, getting dressed, eating, and getting out of bed, and difficulties to perform at least one more extenuating activity such as walking long distances, intense exercise, and climbing stairs. Finally, a new set of 9 questions were asked only in the 2009 and 2012 waves related to self-perception of state of mind, such as feeling depressed, happy, alone, sad, tired, having lots of energy or restless sleep, and enjoying life.

\section{Stylized Facts}

The reform changed the incentives that different groups of the population, either retired or not, might have to save, to work and to contribute to the pension system. To evaluate the effect of the reforms on the group of outcomes detailed in the previous section, we exploit the differential impact that the reform have in these sub-groups. Table 1 depicts the main descriptive statistics for the sample of individuals that we were able to follow across the four survey rounds (2004 through 2012) and that were merged to administrative records on pensions and contributions. Our sample involves 7,345 individuals that represent between $42.6 \%$ and $58.6 \%$ of the population, according to our factors of expansion. The levels of attrition across waves a relatively stable between 2004 and 2009, but they sharply increase by 2012 . For example, the sample tracked between 2004 and 2009 included 10,075 individuals with an average of $10 \%$ attrition between waves, but from wave 2009 to 2012 we observe a $27 \%$ of attrition due to fieldwork problems of the EPS $2012^{4}$.

Regarding the sample characteristics, the percentage decreased over time from $56.5 \%$ in 2004 to $50.4 \%$ in 2012. We observe a high degree of variation by cohort, which is important our identification strategy. In 2012, the fraction of individuals belonging to the 1940, 1950, 1960, 1970 and 1980 cohorts were $10.9 \%, 19.0 \%, 21.0 \%, 18.9 \%$ and $23.9 \%$ respectively, with a small fraction belonging to older cohorts. Consistent with the aging trend of the sample, the mean age of the panel increased from 39.6 years old in 2004 to 47.3 years old in 2012. Mean household income and mean per capita household incomes (in US dollars per month) show some slight increase across survey waves, with the highest increase occurring between 2009 and 2012. Importantly, we do observe that both household income and per capita income including pension benefits is larger than without pension benefits. While these changes are not significant for the whole sample, we will show below that once the sample is restricted to eligible beneficiaries of the reform around the time of retirement, pensions significantly increase both per capita and household income. Finally, our sample does a good job in representing households that are eligible for the PBS and the APS (those below the 60th percentile of an index that includes household income, assets and other dimensions of poverty captured by the Ficha de Proteccion Social survey). While we would expect that just about $60 \%$ of the sample is eligible to the new benefits, because we adopt an approximation of the index used for eligibility based on survey records and because of attrition, the estimated proportion might not coincide perfectly with the 60th percentile. Overall, we observe a high degree of variation by age,

\footnotetext{
${ }^{4}$ Comment on the fieldwork problem and source
} 
gender, cohort and income that is a necessary condition for the estimation of a robust first stage in our estimation procedure.

\begin{tabular}{|c|c|c|c|c|}
\hline Descriptive Statistics & 2004 & 2006 & 2009 & 2012 \\
\hline N Obs. & 7,345 & 7,345 & 7,345 & 7,345 \\
\hline Expanded Sample & $4,702,191$ & $5,306,558$ & $5,921,201$ & $7,127,836$ \\
\hline Expanded sample/ population (\%) & 42.6 & 42.7 & 46.4 & 58.6 \\
\hline \multirow[t]{2}{*}{ Women(\%) } & 56.5 & 56.1 & 56.1 & 50.4 \\
\hline & $(0.620)$ & $(0.907)$ & (0.956) & (1.159) \\
\hline \multirow[t]{2}{*}{ 1910Cohort } & 0.1 & 0.1 & 0.1 & 0.1 \\
\hline & $(0.042)$ & $(0.034)$ & $(0.041)$ & $(0.028)$ \\
\hline \multirow[t]{2}{*}{1920 Cohort } & 2.5 & 1.5 & 1.5 & 1.5 \\
\hline & $(0.215)$ & $(0.131)$ & $(0.146)$ & $(0.165)$ \\
\hline \multirow[t]{2}{*}{1930 Cohort } & 9.1 & 6.2 & 5.8 & 4.8 \\
\hline & $(0.365)$ & $(0.285)$ & $(0.357)$ & $(0.339)$ \\
\hline \multirow[t]{2}{*}{1940 Cohort } & 15.9 & 11.0 & 13.5 & 10.9 \\
\hline & $(0.463)$ & $(0.384)$ & $(0.543)$ & $(0.524)$ \\
\hline \multirow[t]{2}{*}{1950 Cohort } & 22.6 & 16.4 & 20.3 & 19.0 \\
\hline & $(0.527)$ & $(0.476)$ & $(0.648)$ & $(0.667)$ \\
\hline \multirow[t]{2}{*}{1960 Cohort } & 24.3 & 20.6 & 20.9 & 21.0 \\
\hline & $(0.539)$ & $(0.551)$ & $(0.601)$ & $(0.681)$ \\
\hline \multirow[t]{2}{*}{1970 Cohort } & 18.0 & 16.1 & 17.4 & 18.9 \\
\hline & $(0.482)$ & $(0.487)$ & $(0.553)$ & $(0.694)$ \\
\hline \multirow[t]{2}{*}{1980 Cohort } & 7.4 & 28.1 & 20.5 & 23.9 \\
\hline & $(0.345)$ & (1.138) & (1.189) & (1.493) \\
\hline \multirow[t]{2}{*}{ Age } & 39.6 & 42.1 & 45.4 & 47.3 \\
\hline & $(0.188)$ & $(0.320)$ & $(0.366)$ & $(0.439)$ \\
\hline \multirow[t]{2}{*}{ Mean Household Income (with pension) } & 999 & 1,119 & 1,040 & 1,356 \\
\hline & (20.209) & $(25.410)$ & $(38.469)$ & $(30.501)$ \\
\hline \multirow[t]{2}{*}{ Mean Household Income (without pension) } & 969 & 1,099 & 1,015 & 1,312 \\
\hline & $(20.099)$ & $(25.338)$ & $(38.380)$ & $(30.135)$ \\
\hline \multirow[t]{2}{*}{ Mean PerCapita Income (with pension) } & 275 & 298 & 294 & 442 \\
\hline & $(6.558)$ & $(7.470)$ & $(14.772)$ & (13.945) \\
\hline \multirow[t]{2}{*}{ Mean PerCapita Income (without pension) } & 264 & 290 & 284 & 422 \\
\hline & $(6.469)$ & (7.368) & $(14.554)$ & (13.673) \\
\hline \multirow{3}{*}{$\begin{array}{l}\% \text { of Households with per capita income below } \\
\text { percentile } 60 \text { th }\end{array}$} & & & & \\
\hline & 59,3 & 55,3 & 56,5 & 54.4 \\
\hline & $(0,537)$ & $(0,653)$ & $(0,725)$ & $(0,035)$ \\
\hline
\end{tabular}

Table 1: Sample Descriptive Statistics

Table 2 depicts labor market outcomes for non-retired females and males across survey waves. Female labor participation (active in the labor market) and employment rates are substantially smaller than males in Chilean labor markets. The percentage of females employed was 46.0\% in 2004, 46.5\% in 2009 and $53.5 \%$ in 2012. In contrast, the percentage of males employed was $81.2 \%$ in $2004,81.4 \%$ in 2009 and $83.8 \%$ in 2012. Similar gender gaps can be observed in the percentage of individuals that are active in the labor market. Unemployment rates slightly fall from 2004 to 2012 for both males and females, but they are fairly comparable across gender. Importantly, the gender gap in contribution rates resulted from matching survey and administrative records is quite remarkable. The fraction of females contributing to the DC pension system was $28.6 \%$ in $2004,30.4 \%$ in 2006, 31.3\% in 2009 and $36.4 \%$ in 2012, while in the case of males these rates were $53.3 \%, 54.2 \%, 54.8 \%$ and $60.9 \%$. Contributory behavior has been at the center of the definition of formal or informal labor supply in Latin American Countries. Therefore, these patterns reflect an important reality of Chilean labor markets: females have much lower levels of 
attachment to the labor markets, in particular to formal jobs, which is a determinant factor of the low replacement rates offered by the Chilean DC pension system among them.

\begin{tabular}{l|rrrr|rrrr}
\hline Labor Outcomes & \multicolumn{4}{|c|}{ Females } & \multicolumn{4}{c}{ Males } \\
& $\mathbf{2 0 0 4}$ & $\mathbf{2 0 0 6}$ & $\mathbf{2 0 0 9}$ & $\mathbf{2 0 1 2}$ & $\mathbf{2 0 0 4}$ & $\mathbf{2 0 0 6}$ & $\mathbf{2 0 0 9}$ & $\mathbf{2 0 1 2}$ \\
\hline \hline Employed (\%) & 46.0 & 48.7 & 46.5 & 53.5 & 81.2 & 80.1 & 81.4 & 83.8 \\
& $(0.866)$ & $(1.188)$ & $(1.284)$ & $(1.387)$ & $(0.715)$ & $(1.316)$ & $(1.226)$ & $(1.311)$ \\
Unemployed (\%) & 16.4 & 22.0 & 14.5 & 6.1 & 15.3 & 17.4 & 15.6 & 5.5 \\
& $(0.637)$ & $(1.063)$ & $(0.925)$ & $(0.583)$ & $(0.656)$ & $(1.163)$ & $(1.189)$ & $(1.019)$ \\
Active (\%) & 54.9 & 59.2 & 53.5 & 56.0 & 86.5 & 87.2 & 85.1 & 84.9 \\
& $(0.873)$ & $(1.156)$ & $(1.250)$ & $(1.368)$ & $(0.628)$ & $(1.043)$ & $(1.185)$ & $(1.299)$ \\
Contributes (\%) & 28.6 & 30.4 & 31.3 & 36.4 & 53.3 & 54.2 & 54.8 & 60.9 \\
& $(0.751)$ & $(1.096)$ & $(1.302)$ & $(1.457)$ & $(0.912)$ & $(1.423)$ & $(1.477)$ & $(1.734)$ \\
\hline
\end{tabular}

Table 2: Labor outcomes among non-retired individuals over time, males and females

Table 3 describes the evolution of poverty rates and income inequality for females and males across survey waves, based on measures of income per capita. We divide the sample between pensioners and non-pensioners to depict the effect of adding pension benefits before and after the reforms to each of these measures. In the case of non-pensioners, we observe a fairly stable evolution of poverty rates and income inequality over time. Poverty rates are substantially higher for females than males. The percentage of old age females below the poverty line in 2004 was $34.4 \%$ and slightly decreased to $29.6 \%$ in 2012 . Among males, these percentages were $27.7 \%$ and $20.9 \%$, respectively. Income inequality, measured through the Gini coefficient, shows similar trends between non-retired females and males. While for females the index is 0.47 in 2004 and 0.48 in 2012, for males the indexes are 0.48 and 0.45 in 2004 and 2012, respectively. The overall picture for individuals already claiming pension benefits is substantially different. Poverty rates between males and females without pension benefits are remarkably similar, suggesting that gender differences in poverty rates among non-pensioners are mostly driven by much lower female labor participation (Table 2). When pension benefits are included, poverty rates decrease significantly both among females and males. Among females, the poverty rate with pension was $32.8 \%$ in 2004 and $22.6 \%$ in 2012, while among males these rates were $31.3 \%$ and $28.9 \%$ respectively. The data suggests that the 2008 pension reforms has some significant impacts in poverty rates. Among females, pension benefits decrease poverty rates in $26.3 \%$ in 2004 (from $44.5 \%$ to $32.8 \%$ ), in $20.4 \%$ in 2009 (when the reform is just starting to be implemented), and in $48.5 \%$ in 2012 when the reform is fully implemented (from $48.9 \%$ to $22.6 \%$ ). The reduction in poverty among males follows a similar trend: a $33.8 \%$ in 2004, a $25.8 \%$ in 2009 and a $40.65 \%$ in 2012 . Similarly, the largest reductions in income inequality without and with pensions, both for females and males, are in recent years when the new reforms are in place. 


\begin{tabular}{|l|rrrr|rrrr}
\hline Poverty and Inequality Measures & \multicolumn{5}{|c|}{ Females } & \multicolumn{5}{c}{ Males } \\
& $\mathbf{2 0 0 4}$ & $\mathbf{2 0 0 6}$ & $\mathbf{2 0 0 9}$ & $\mathbf{2 0 1 2}$ & $\mathbf{2 0 0 4}$ & $\mathbf{2 0 0 6}$ & $\mathbf{2 0 0 9}$ & $\mathbf{2 0 1 2}$ \\
\hline \hline Non-Pensioner & & & & & & & \\
$\quad$ Poverty rate & $34.4 \%$ & $35.0 \%$ & $36.9 \%$ & $29.6 \%$ & $27.7 \%$ & $26.8 \%$ & $36.1 \%$ & $20.9 \%$ \\
$\quad$ Inequality (Gini coef.) & 0.47 & 0.48 & 0.46 & 0.48 & 0.48 & 0.49 & 0.52 & 0.45 \\
\hline Pensioner & & & & & & & & \\
$\quad$ Poverty rate & & & & & & & & \\
$\quad$ without pension & $44.5 \%$ & $50.1 \%$ & $55.3 \%$ & $43.9 \%$ & $47.3 \%$ & $48.8 \%$ & $53.1 \%$ & $48.7 \%$ \\
$\quad$ with pension & $32.8 \%$ & $39.3 \%$ & $44.0 \%$ & $22.6 \%$ & $31.3 \%$ & $33.0 \%$ & $39.4 \%$ & $28.9 \%$ \\
\hline Inequality (Gini coef.) & & & & & & & & \\
$\quad$ without pension & 0.55 & 0.56 & 0.67 & 0.50 & 0.57 & 0.62 & 0.56 & 0.59 \\
$\quad$ with pension & 0.53 & 0.54 & 0.64 & 0.46 & 0.55 & 0.58 & 0.52 & 0.54 \\
\hline
\end{tabular}

Table 3: Measures of poverty and inequality over time, males and females

While outcomes in Tables 2 and 3 have been previously analyzed in Attanasio et al. (2014) and in this paper we replicate those results in section 6, the following set of tables add new dimensions of outcomes that have not been previously addressed in the literature. Table 4 describes the evolution of aggregate expenditures in food, clothing, household utilities, transport and domestic help, separately for pensioners and non-pensioners. Aggregate expenditures reflect household consumption so we do not observe large differences between males and females (not reported). Among the five categories reported in Table 4, we observe substantial differences in household consumption between pensioners than non-pensioners. Expenditures in food range from 59\% in 2004 to 57\% in 2012 for pensioners, while the same percentages are 55\% in 2004 and $54 \%$ in 2012 for non-pensioners. A similar pattern is observed for the proportion of household expenditures in utilities such as gas, electricity, water and phone bills, with proportions that are 3\%-5\% higher for pensioners than non-pensioners. In contrast, expenditures that are likely to increase among individuals that work such as clothes and transport, the proportions are consistently larger among non-pensioners. The proportion of expenditures in clothing range from 4\% in 2009 to $5 \%$ in 2012 for pensioners, while the same figures for non-pensioners are 7\% in 2009 and $8 \%$ in 2012. Similarly, the proportion of household expenditures in transport are in the range 7\%-9\% among pensioners, and in the range $10 \%-12 \%$ among non-pensioners.

\begin{tabular}{l|rrrr|rrrr}
\hline Aggregate Expenditures & \multicolumn{5}{|c|}{ Pensioner } & \multicolumn{4}{c}{ Non-pensioner } \\
& $\mathbf{2 0 0 4}$ & $\mathbf{2 0 0 6}$ & $\mathbf{2 0 0 9}$ & $\mathbf{2 0 1 2}$ & $\mathbf{2 0 0 4}$ & $\mathbf{2 0 0 6}$ & $\mathbf{2 0 0 9}$ & $\mathbf{2 0 1 2}$ \\
\hline \hline $\begin{array}{l}\text { Proportion of expenditures } \\
\text { in food }\end{array}$ & 0.59 & 0.57 & 0.58 & 0.57 & 0.55 & 0.53 & 0.54 & 0.54 \\
& $(0.166)$ & $(0.174)$ & $(0.151)$ & $(0.156)$ & $(0.165)$ & $(0.167)$ & $(0.150)$ & $(0.148)$ \\
Proportion of expenditures & & & & & & & & \\
in clothing & 0.05 & 0.05 & 0.04 & 0.05 & 0.08 & 0.09 & 0.07 & 0.08 \\
& $(0.073)$ & $(0.082)$ & $(0.072)$ & $(0.070)$ & $(0.098)$ & $(0.102)$ & $(0.086)$ & $(0.093)$ \\
$\begin{array}{l}\text { Proportion of expenditures } \\
\text { in utilities (water, gas, } \\
\text { phone, etc) }\end{array}$ & & & & & & & & \\
& 0.27 & 0.29 & 0.30 & 0.29 & 0.24 & 0.25 & 0.27 & 0.26 \\
$\begin{array}{l}\text { Proportion of expenditures } \\
\text { in transport }\end{array}$ & $(0.135)$ & $(0.153)$ & $(0.128)$ & $(0.132)$ & $(0.121)$ & $(0.127)$ & $(0.116)$ & $(0.114)$ \\
& 0.07 & 0.08 & 0.08 & 0.09 & 0.11 & 0.12 & 0.10 & 0.12 \\
& $(0.093)$ & $(0.099)$ & $(0.088)$ & $(0.091)$ & $(0.112)$ & $(0.118)$ & $(0.102)$ & $(0.104)$ \\
$\begin{array}{l}\text { Proportion of expenditures } \\
\text { in domestic help }\end{array}$ & & & & & & & & \\
& 0.01 & 0.01 & 0.01 & 0.01 & 0.01 & 0.01 & 0.01 & 0.00 \\
& $(0.056)$ & $(0.058)$ & $(0.049)$ & $(0.052)$ & $(0.048)$ & $(0.052)$ & $(0.047)$ & $(0.036)$ \\
\hline
\end{tabular}

Table 4: Aggregate expenditures over time, males and females 
Table 5 describes self-care behavioral differences between males and females over time. While females practice less sports than males, they tend to adopt less harmful behaviors such as smoking and alcohol consumption. The percentage of females that exercise at least once a week was $17.8 \%$ in 2004 and $15.1 \%$ in 2012 , and the same figures for males were $31.3 \%$ and $25.2 \%$ respectively. The decrease of this behavior over time is consistent with the aging of the panel, and differences are even sharper when comparing active workers versus retired (not shown). For example, among females, the proportion of non-pensioners practicing sports at least once a week was $17.2 \%$ in 2004 and $13.1 \%$ in 2012, while the same rates were $14.1 \%$ and $9.2 \%$ among pensioners. Among non-pensioner males, 33.7\% practiced sports in 2004 and $24.1 \%$ in 2012, while among pensioners these rates were $17.1 \%$ in 2004 and $11.3 \%$ in 2012. Regarding daily consumption of tobacco, the proportion of females adopting this behavior was $31.5 \%$ in 2004 and 30.5\% in 2012, and for males was 37.9\% in 2004 and 35.1\% in 2012. Analyzing these figures separately for pensioners and non-pensioners, the prevalence of daily tobacco consumption is between 2.5-2.9 times higher among non-pensioners regardless of gender. Finally, the gender gap in alcohol consumption is even sharper. Among females, 22.2\% in 2004 and $25.6 \%$ in 2012 report to consume at weekly at least one of three alcoholic beverages, while these rates for males are $55.5 \%$ in 2004 and 58.2 in 2012. Differences between pensioners and non-pensioners vary by gender. Alcohol consumption among pensioner females are roughly half the rates observed among non-pensioners, while in the case of males, in average pensioners consume only $20 \%$ less alcohol than non-pensioners.

\begin{tabular}{l|rrrr|rrrr}
\hline Behaviors & \multicolumn{4}{|c}{ Females } & \multicolumn{4}{c}{ Males } \\
& $\mathbf{2 0 0 4}$ & $\mathbf{2 0 0 6}$ & $\mathbf{2 0 0 9}$ & $\mathbf{2 0 1 2}$ & $\mathbf{2 0 0 4}$ & $\mathbf{2 0 0 6}$ & $\mathbf{2 0 0 9}$ & $\mathbf{2 0 1 2}$ \\
\hline \hline Practice sport at least once a & & & & & & & & \\
week (\%) & 17.8 & 17.4 & 14.4 & 15.1 & 31.3 & 32.1 & 24.9 & 25.2 \\
& $(0.623)$ & $(0.748)$ & $(0.901)$ & $(0.805)$ & $(0.678)$ & $(0.883)$ & $(0.859)$ & $(0.801)$ \\
Cigarettes current use (\%) & 31.5 & 31.2 & 30.9 & 30.5 & 37.9 & 39.2 & 38.8 & 35.1 \\
& $(0.746)$ & $(0.894)$ & $(1.120)$ & $(1.001)$ & $(0.706)$ & $(0.909)$ & $(0.996)$ & $(0.943)$ \\
Alcohol current use (\%) & 22.2 & 29.4 & 26.5 & 25.6 & 55.5 & 62.0 & 57.8 & 58.2 \\
& $(0.685)$ & $(0.891)$ & $(1.040)$ & $(0.987)$ & $(0.721)$ & $(0.859)$ & $(0.915)$ & $(0.899)$ \\
\hline
\end{tabular}

Table 5: Self-care behavior indicators over time, males and females

Table 6 describes our main measures of physical health. A lower and higher than normal BMI index is relatively higher for females than males, and a low BMI is slightly decreasing over time for males. Table 9 in the appendix shows no substantial differences between pensioners and non-pensioners. Other measures of physical health indicators show sharper contrasts between males and females, and between pensioners and non-pensioners. Females have much poorer measures of physical health than males among several indicators. Among females, 43.0\% in 2004 and 46.6\% in 2012 were diagnosed with at least one serious illness, while these percentages for males are $24.9 \%$ in 2004 and $26.1 \%$ in 2012. Among females, 37.6\% of non-pensioner and $74.0 \%$ of pensioners were diagnosed with any disease over the last two years, while these rates for males were $19.5 \%$ for non-pensioners and $60.0 \%$ for pensioners (Table 9). Among females, $12.1 \%$ in 2004 and $12.0 \%$ in 2012 were diagnosed depression, while these percentages for males were only $2.7 \%$ and $3.1 \%$. However, males show a larger increase in depression rates when they retire, from $2.9 \%$ among non-pensioners to $5.4 \%$ for pensioners. Diagnosed high blood pressure is also substantially larger for females (about 10 percentage points higher), with sharp increases after retirement: among females, $18.8 \%$ of non-pensioner and $51.7 \%$ of pensioners have high blood pressure, and among males these figures are $10.0 \%$ and $39.4 \%$. These patterns by gender and retirement status remain strongly similar among other illnesses such as respiratory problems, diabetes, cardiac problems and arthritis. 


\begin{tabular}{|c|c|c|c|c|c|c|c|c|}
\hline \multirow[t]{2}{*}{ Physical Health Outcomes } & \multicolumn{4}{|c|}{ Females } & \multicolumn{4}{|c|}{ Males } \\
\hline & 2004 & 2006 & 2009 & 2012 & 2004 & 2006 & 2009 & 2012 \\
\hline \multirow[t]{2}{*}{ Low BMI (\%) } & 16 & 18,2 & 18,9 & 17.9 & 16,9 & 12,9 & 13,0 & 12.9 \\
\hline & $(1.367)$ & (1.357) & $(1.626)$ & $(1.456)$ & $(1.110)$ & $(0.921)$ & (1.153) & (1.011) \\
\hline \multirow[t]{2}{*}{ High BMI (\%) } & 22,3 & 19,2 & 18,7 & 19.0 & 21,6 & 19,9 & 19,3 & 20.1 \\
\hline & $(1.526)$ & $(1.350)$ & (1.777) & $(1.654)$ & $(1.234)$ & (1.125) & (1.411) & (1.399) \\
\hline \multirow{3}{*}{$\begin{array}{l}\text { Diagnosed of any disease, last two } \\
\text { years (\%) }\end{array}$} & & & & & & & & \\
\hline & 43.0 & 41.6 & 45.2 & 46.6 & 24.9 & 22.3 & 24.3 & 26.1 \\
\hline & $(0.866)$ & (1.123) & $(1.237)$ & $(1.388)$ & $(0.778)$ & $(1.045)$ & $(1.032)$ & $(1.321)$ \\
\hline \multicolumn{9}{|l|}{ Diagnosed asthma or emphysema } \\
\hline \multirow[t]{2}{*}{ (respiratory problems) $(\%)$} & 3.9 & 4.8 & 4.5 & 5.2 & 2.8 & 2.5 & 2.8 & 3.0 \\
\hline & $(0.327)$ & $(0.543)$ & $(0.474)$ & $(0.547)$ & $(0.302)$ & $(0.526)$ & $(0.467)$ & $(0.639)$ \\
\hline \multirow{2}{*}{ Diagnosed depression (\%) } & 12.1 & 14.1 & 14.4 & 12.0 & 2.7 & 3.3 & 3.5 & 3.1 \\
\hline & $(0.560)$ & $(0.721)$ & $(0.810)$ & $(0.847)$ & $(0.295)$ & $(0.516)$ & $(0.406)$ & $(0.604)$ \\
\hline \multirow[t]{2}{*}{ Diagnosed diabetes (\%) } & 6.5 & 6.6 & 8.3 & 10.9 & 4.7 & 4.2 & 6.4 & 6.5 \\
\hline & $(0.450)$ & $(0.414)$ & $(0.560)$ & $(0.744)$ & $(0.391)$ & $(0.370)$ & $(0.556)$ & $(0.641)$ \\
\hline \multirow{3}{*}{$\begin{array}{l}\text { Diagnosed hypertension or high blood } \\
\text { pressure (\%) }\end{array}$} & & & & & & & & \\
\hline & 23.2 & 22.3 & 26.7 & 24.0 & 13.1 & 12.2 & 14.3 & 14.7 \\
\hline & $(0.750)$ & $(0.790)$ & $(0.987)$ & $(1.004)$ & $(0.603)$ & $(0.750)$ & $(0.758)$ & $(0.866)$ \\
\hline \multirow[t]{2}{*}{ Diagnosed cardiac problems (\%) } & 5.2 & 6.0 & 6.0 & 4.1 & 3.7 & 3.5 & 3.2 & 2.9 \\
\hline & $(0.385)$ & $(0.479)$ & $(0.608)$ & $(0.431)$ & $(0.342)$ & $(0.359)$ & $(0.327)$ & $(0.365)$ \\
\hline \multirow{3}{*}{$\begin{array}{l}\text { Diagnosed arthritis or osteoarthritis } \\
\text { (\%) }\end{array}$} & & & & & & & & \\
\hline & 9.9 & 8.7 & 11.7 & 12.3 & 2.5 & 2.4 & 3.1 & 3.6 \\
\hline & $(0.526)$ & $(0.517)$ & $(0.661)$ & $(0.703)$ & $(0.284)$ & $(0.338)$ & $(0.338)$ & $(0.422)$ \\
\hline
\end{tabular}

Table 6: Physical health variables pensioners and non-pensioners, males and females

Table 7 describes gender differences in the use of medical services and associated medical expenditures. Our constructed index of individuals currently not under medical treatment but needing it shows that females are twice more likely than males to be in this situation: $7.0 \%$ of females in 2004 and $6.7 \%$ in 2012 had this health risk factor, while observed rates in their males counterparts were 3.7\% in 2004 and $3.1 \%$ in 2012 . The risk prevalence is substantially larger among pensioners than non-pensioners, as shown in Table 10 in the appendix: in average, among females, $6.8 \%$ of non-pensioners and $8.5 \%$ of pensioners are in this situation, while the analogous rates for males are 3.9\% of non-pensioners and $6.1 \%$ of pensioners. Monthly expenditures in medicines are surprisingly similar among males and females (around $25 \mathrm{US} \$ /$ month), except for 2012, where in average females spent $60.6 \mathrm{US} \$ /$ month and males only 19.8 US\$/month. Expenditures in alternative medicine over the last two years also show a sharp increase in 2012, but in this case both for females and males. Among females, the average expenditures increases from an average of $75 \mathrm{US} \$ /$ month for the period 2004-2009, to 101.1 \$US/month in 2012. While males report lower expenditures, we also observe a sharp increase in 2012. Overall, gender differences in these expenditures need to be taken with caution because they likely represent household rather than individual consumption. Comparing pensioners against non-pensioners, we observe in Table 10 that expenditures in traditional and alternative medicines are substantially larger among pensioners, both for males and females. Regarding out-of-pocket expenditures in the last dental care visit, females report to have spent 47.3 US\$ in 2004 and 32.3 US\$ in 2012, while the amounts for males were 35.6US\$ and 22.4 US\$. Expenditures in the last visit to the doctor were marginally larger for males than females, however, females report to go to the doctor more often. The average number of visits to the doctor over the last two years among females was 5.3 in 2004 and 8.1 in 2012, while these rates for males were 2.7 in 2004 and 3.4 in 2012. Similar patterns but with a much lower number of visits over the last two years are observed for visits to the emergency room, dental care visits, and medical tests visits. Unsurprisingly, differences in the number of visits to the doctor are significantly larger among pensioners (Table 10). Among females, 
the average number of visits to the doctor over the last two years was 9.27 for pensioners and 5.94 for non-pensioners, and the same average number of visits for males were 7.43 and 2.45 .

\begin{tabular}{|c|c|c|c|c|c|c|c|c|}
\hline \multirow[t]{2}{*}{ Use and expenditures in medical services } & \multicolumn{4}{|c|}{ Females } & \multicolumn{4}{|c|}{ Males } \\
\hline & 2004 & 2006 & 2009 & 2012 & 2004 & 2006 & 2009 & 2012 \\
\hline Not under treatment but need it (\%) & $\begin{array}{r}7.0 \\
(0.443)\end{array}$ & $\begin{array}{r}9.9 \\
(0.655)\end{array}$ & $\begin{array}{r}7.1 \\
(0.565)\end{array}$ & $\begin{array}{r}6.7 \\
(0.752)\end{array}$ & $\begin{array}{r}3.7 \\
(0.332)\end{array}$ & $\begin{array}{r}5.9 \\
(0.741)\end{array}$ & $\begin{array}{r}3.7 \\
(0.373)\end{array}$ & $\begin{array}{r}3.1 \\
(0.381)\end{array}$ \\
\hline OOP monthly expenditure in medicines (US & & & & & & & & \\
\hline \$) & $\begin{array}{r}28.6 \\
(0.982)\end{array}$ & $\begin{array}{r}26.5 \\
(1.305)\end{array}$ & $\begin{array}{r}23.1 \\
(1.638)\end{array}$ & $\begin{array}{r}60.6 \\
(3.060)\end{array}$ & $\begin{array}{r}26.6 \\
(1.428)\end{array}$ & $\begin{array}{r}24.7 \\
(1.684)\end{array}$ & $\begin{array}{r}25.3 \\
(6.128)\end{array}$ & $\begin{array}{r}19.8 \\
(2.163)\end{array}$ \\
\hline $\begin{array}{l}\text { OOP expenditure in alternative medicine } \\
\text { last two years (US \$) }\end{array}$ & $\begin{array}{r}73.9 \\
(11.193)\end{array}$ & $\begin{array}{r}64.2 \\
(19.582)\end{array}$ & $\begin{array}{r}77.2 \\
(32.994)\end{array}$ & $\begin{array}{r}101.1 \\
(40.305)\end{array}$ & $\begin{array}{r}35.4 \\
(8.331)\end{array}$ & $\begin{array}{r}34.4 \\
(10.611)\end{array}$ & $\begin{array}{r}18.5 \\
(6.151)\end{array}$ & $\begin{array}{r}46.7 \\
(14.305)\end{array}$ \\
\hline OOP expenditure last dental care visit (US \$) & $\begin{array}{r}47.3 \\
(10.682)\end{array}$ & $\begin{array}{r}40.0 \\
(3.440)\end{array}$ & $\begin{array}{r}31.6 \\
(2.472)\end{array}$ & $\begin{array}{r}32.3 \\
(3.576)\end{array}$ & $\begin{array}{r}35.6 \\
(2.331)\end{array}$ & $\begin{array}{r}29.5 \\
(2.329)\end{array}$ & $\begin{array}{r}22.3 \\
(1.770)\end{array}$ & $\begin{array}{r}22.4 \\
(4.475)\end{array}$ \\
\hline $\begin{array}{l}\text { Out of pocket (OOP) expenditure last visit } \\
\text { to doctor (CLP \$) }\end{array}$ & $\begin{array}{r}5.0 \\
(0.637)\end{array}$ & $\begin{array}{r}3.8 \\
(0.248)\end{array}$ & $\begin{array}{r}4.2 \\
(0.877)\end{array}$ & $\begin{array}{r}5.1 \\
(0.988)\end{array}$ & $\begin{array}{r}10.6 \\
(2.448)\end{array}$ & $\begin{array}{r}8.8 \\
(1.256)\end{array}$ & $\begin{array}{r}8.8 \\
(1.474)\end{array}$ & $\begin{array}{r}9.8 \\
(1.610)\end{array}$ \\
\hline Number visits to the doctor last two years & $\begin{array}{r}5.3 \\
(0.144)\end{array}$ & $\begin{array}{r}6.2 \\
(0.176)\end{array}$ & $\begin{array}{r}7.1 \\
(0.200)\end{array}$ & $\begin{array}{r}8.1 \\
(0.250)\end{array}$ & $\begin{array}{r}2.7 \\
(0.091)\end{array}$ & $\begin{array}{r}2.7 \\
(0.079)\end{array}$ & $\begin{array}{r}3.5 \\
(0.127)\end{array}$ & $\begin{array}{r}3.4 \\
(0.118)\end{array}$ \\
\hline $\begin{array}{l}\text { Number visits emergency room last two } \\
\text { years }\end{array}$ & $\begin{array}{r}0.7 \\
(0.051)\end{array}$ & $\begin{array}{r}1.2 \\
(0.089)\end{array}$ & $\begin{array}{r}0.9 \\
(0.059)\end{array}$ & $\begin{array}{r}1.5 \\
0 . .71\end{array}$ & $\begin{array}{r}0.4 \\
(0.025)\end{array}$ & $\begin{array}{r}0.5 \\
(0.029)\end{array}$ & $\begin{array}{r}0.6 \\
(0.047)\end{array}$ & $\begin{array}{r}0.6 \\
(0.051)\end{array}$ \\
\hline Number dental care visits last two years & $\begin{array}{r}1.0 \\
(0.067)\end{array}$ & $\begin{array}{r}1.2 \\
(0.059)\end{array}$ & $\begin{array}{r}1.0 \\
(0.089)\end{array}$ & $\begin{array}{r}1.4 \\
(0.090)\end{array}$ & $\begin{array}{r}0.5 \\
(0.034)\end{array}$ & $\begin{array}{r}0.7 \\
(0.051)\end{array}$ & $\begin{array}{r}0.6 \\
(0.042)\end{array}$ & $\begin{array}{r}0.7 \\
(0.051)\end{array}$ \\
\hline Number medical tests (laboratory. $\mathbf{x}$-rays) & $\begin{array}{r}1.6 \\
(0.078) \\
\end{array}$ & $\begin{array}{r}2.3 \\
(0.101) \\
\end{array}$ & $\begin{array}{r}2.1 \\
(0.076) \\
\end{array}$ & $\begin{array}{r}2.3 \\
(0.081)\end{array}$ & $\begin{array}{r}0.7 \\
(0.043)\end{array}$ & $\begin{array}{r}0.9 \\
(0.042) \\
\end{array}$ & $\begin{array}{r}1.1 \\
(0.051) \\
\end{array}$ & $\begin{array}{r}1.0 \\
(0.045) \\
\end{array}$ \\
\hline
\end{tabular}

Table 7: Use and expenditures in medical services over time, males and females

To finalize the description of the data, Table 8 shows our main indicators of subjective well-being. Selfperception of good health is consistently lower for females than males. The percentage of females reporting to have good health is $56.9 \%$ in 2004 and $58.7 \%$ in 2012, while these percentages for males are $69.9 \%$ in 2004 and $70.9 \%$ in 2012 . Consistently, females perceive themselves in poorer health than males. Unsurprisingly, similar patterns to previous health indicators emerge when comparing pensioners and non-pensioners. In Table 11 in the appendix, the fraction of non-pensioner females that the perceive themselves in good health is twice as large as pensioner females, and the opposite is true for their perception of bad health. A similar trend is observed for males. Our index measuring difficulties in performing daily activities shows an increasing trend over time that is consistent with aging. Among females, $6.2 \%$ in 2004 and $13.7 \%$ in 2012 report to have these problems, and the same percentages for males are $2.6 \%$ and $7.6 \%$. However, Table 11 shows that while the increase in difficulties to perform daily activities for females increase from $7.5 \%$ to $32.2 \%$ after retirement, for males the increase is even larger, from $3.2 \%$ to $23.5 \%$. The patterns for our indexes of difficulties in daily extenuating and basic activities are identical. We do not observe marked gender differences in the subjective probability of living until certain age. Surprisingly, males and females that are already retired report only marginally higher subjective probabilities of living until ages 65, 75, 85 and 100 than those individuals not retired. 


\begin{tabular}{|c|c|c|c|c|c|c|c|c|}
\hline \multirow[t]{2}{*}{ Subjective well-being } & \multicolumn{4}{|c|}{ Women } & \multicolumn{4}{|c|}{ Men } \\
\hline & 2004 & 2006 & 2009 & 2012 & 2004 & 2006 & 2009 & 2012 \\
\hline \multirow[t]{2}{*}{ Self-perception of good health (\%) } & 56.9 & 62.2 & 55.9 & 58.7 & 69.9 & 74.3 & 72.3 & 70.9 \\
\hline & $(0.866)$ & (1.053) & (1.232) & (1.293) & $(0.829)$ & $(1.005)$ & (1.165) & $(1.524)$ \\
\hline \multirow[t]{2}{*}{ Self-perception of bad health (\%) } & 43.0 & 37.7 & 44.1 & 41.2 & 30.1 & 25.7 & 27.7 & 29.1 \\
\hline & $(0.866)$ & $(1.053)$ & $(1.232)$ & (1.293) & $(0.829)$ & $(1.004)$ & $(1.165)$ & $(1.524)$ \\
\hline \multirow[t]{2}{*}{ Difficulties in daily activities (\%) } & 6.2 & 9.9 & 12.7 & 13.7 & 2.9 & 4.8 & 6.1 & 8.0 \\
\hline & $(0.431)$ & $(0.567)$ & $(0.742)$ & $(0.751)$ & $(0.302)$ & $(0.454)$ & $(0.559)$ & $(0.769)$ \\
\hline \multirow{3}{*}{$\begin{array}{l}\text { Difficulties in daily extenuating } \\
\text { activities (\%) }\end{array}$} & & & & & & & & \\
\hline & 5.8 & 9.6 & 12.2 & 13.1 & 2.6 & 4.3 & 5.8 & 7.6 \\
\hline & $(0.418)$ & $(0.558)$ & $(0.730)$ & $(0.732)$ & $(0.284)$ & $(0.366)$ & $(0.548)$ & $(0.761)$ \\
\hline \multicolumn{9}{|l|}{ Difficulties in daily basic activities } \\
\hline \multirow[t]{2}{*}{ (\%) } & 1.6 & 2.4 & 3.6 & 3.2 & 0.6 & 1.4 & 1.5 & 1.5 \\
\hline & $(0.204)$ & $(0.262)$ & $(0.424)$ & $(0.357)$ & $(0.148)$ & $(0.312)$ & $(0.234)$ & $(0.296)$ \\
\hline \multirow[t]{2}{*}{ Probability of living until age 65} & 81.3 & 78.8 & 79.5 & 86.5 & 82.3 & 80.8 & 81.4 & 87.9 \\
\hline & $(0.462)$ & $(0.661)$ & $(0.663)$ & $(0.669)$ & $(0.471)$ & $(0.703)$ & $(0.829)$ & $(0.773)$ \\
\hline \multirow[t]{2}{*}{ Probability of living until age 75} & 81.2 & 75.3 & 78.8 & 81.1 & 79.3 & 77.1 & 77.4 & 84.2 \\
\hline & $(1.476)$ & (1.533) & (1.896) & (1.537) & (1.605) & (1.567) & $(2.663)$ & $(1.695)$ \\
\hline \multirow[t]{2}{*}{ Probability of living until age 85} & 70.9 & 65.9 & 66.4 & 76.5 & 67.5 & 66.5 & 74.4 & 72.8 \\
\hline & (3.677) & $(3.324)$ & $(3.438)$ & (2.296) & $(4.287)$ & (3.547) & (3.841) & $(4.228)$ \\
\hline \multirow[t]{2}{*}{ Probabilility of living until age 100} & 50.0 & 50.9 & 48.0 & 51.0 & 68.1 & 66.9 & 54.5 & 59.2 \\
\hline & $(12.976)$ & $(7.124)$ & $(7.705)$ & $(5.005)$ & $(11.159)$ & $(8.119)$ & $(10.692)$ & $(4.767)$ \\
\hline
\end{tabular}

Table 8: Subjective well-being indicators over time, males and females.

\section{Results}

The following set of results include six dimension of outcomes: 1) labor market outcomes (formality, self-employment, participation); 2) household expenditures (food, clothing, domestic help); 3) self-care behaviors and measures of physical health (BMI, diagnosed chronic conditions); 4) Medical expenditures (number of visits to the doctor, dental care); 5) Subjective measures of health (self-perception of health, ADLs); and 6) Mental health. Our regressions we include the endogenous variable interacted with age in order to capture non-linearity of the effects ${ }^{5}$.

\subsection{Labor Market Outcomes}

Tables 12 and 13 in the Appendix report the set of labor market outcomes separately for males and females. As discussed above, in the case of labor market outcomes both pension wealth and accrual rates are endogenous variables that are potentially correlated with unobserved characteristics. However, our set of instruments will be able to secure identification for only one endogenous variable. Therefore, we choose to instrument Expected Pension Wealth with dummies for various groups of the population differentially affected by the reform. While we still include accrual rates in the regressions, we cannot interpret those estimates as causal.

Table 12 summarizes our main findings for Linear Probability Models of labor market outcomes for the sample of males. Results with probit regressions show similar marginal effects. An increase of $\$ 100,000$ clp (US\$150) in expected pension wealth induced by the reform does not induces males to change their participation in formal labor markets at any age, where formality is defined as individuals

\footnotetext{
${ }^{5}$ Note: Our preliminary results only include the sample of individuals still not retired by the time of the reform (2008), although a significant fraction of them could retire between this period and the last survey round in 2012. We will update the results with the full set of individuals already retired by 2008 in a next version of the paper.
} 
that have contributed to the pension system for at least sis months over the past year. We study alternative measures of informality that have been proposed in the literature, as well as overall effects in labor market participation. The same increase in expected pension wealth would increase the probability of having a contract by $1.5 \%$ and would reduce self-employment by $1.7 \%$, estimates that are stable for workers across different ages. Finally, an increase in expected pension wealth induced by the reform of that magnitude is unlikely to change overall labor market participation among males. Overall, these results suggest the existence of substitution effects that induce male workers to more formally. While changes in accrual rates cannot be interpreted as causal, it is worth noticing the magnitude of those estimates. An increase in accrual rates of $\$ 100,000 \mathrm{clp}$ (US\$150) is strongly positively associated with formal labor participation for workers older than 24 years old, strongly positively associated with the probability of holding a contract for workers older than 21 years old, and strongly negatively correlated to self-employment for male workers at all ages. Overall, changes in accrual rates are also positively correlated to labor market participation, in particular for older workers.

Table 13 suggests a slightly different picture for females. An increase of \$100,000 (US\$150) in expected pension wealth would decrease the incentives to work formal for females younger than 35 years old and would increase the incentives to work formally in older females $(2.7 \%$ higher formality among those 55 years old). The same change in expected pension wealth induced by the reform would reduce the probability of having a contract among females younger than 30 years old, and would increase the probability of having a contract for older females (3.2\% for females near retirement at 55 years old). In turn, this change would induce a reduction in self-employment rates of about $1.7 \%$, and different from the case of males, would decrease labor market participation in about 3\% among females of all ages. Regarding accrual rates, changes in pension wealth accrued are strongly positively correlated to formal labor participation among and the probability of having a contract, negatively correlated to self-employment, and positively correlated to labor market participation. These associations are much stronger for females near retirement. Overall, our results suggest a strong substitution effect from accrual rates that, in the case of labor market participation, more than offset negative income effects arising from changes in the level of pension wealth.

\subsection{Aggregate Expenditures}

Table 14 reports the impacts of the reform in household aggregate expenditures. Notice that while an increases in individual expected pension wealth do not induce any significant change in the intercept of household expenditures, the interactions with age in four of these items (food, domestic help, utilities and clothing) are positive and significant. As a result, an increase in \$100,000clp (US\$150) in individual expected pension wealth for a head of the household of 55 years old would result in an increase of $\$ 3,272$ clp (US\$5.03) in monthly expenditures in food, and increase of \$1,387 (US\$2.13) in monthly expenditures in domestic help, and an increase of \$1,392clp (US\$2.14) in monthly expenditures in utilities, and an increase of \$519.6clp (US\$ 0.79) in monthly expenditures in clothing.

\subsection{Self-care Behaviors and Physical Health}

Tables 15 and 16 show no significant impacts of increases in expected pension wealth in behaviors including the practice of sports and alcohol consumption. This is true for both males and females. Table 
17 shows our results regarding objective measures of physical health for males. Besides a marginally negative effect on BMI that is not very robust and with a low economic magnitude, the effects on other outcomes such as being diagnosed with any disease, or chronic diseases like depression, diabetes or cardiac problems are statistically zero. A similar picture can be observed for females in Table 18, with the exception of the diagnostic of diabetes. An increase of \$100,000clp (US\$150) in expected pension wealth would lead to a reduction in the diagnostic of diabetes of about $4 \%$ among females older than 55 years old.

\subsection{Medical Expenditures}

Tables 19 and 20 reports the impacts of an increase of $\$ 100,000$ (US\$150) in expected pension on measures of medical expenditures reflected in measures such as the number of visits to the doctor, visits to the emergency room or dental care visits over the last two years. Among males of 60 years old (Table 19), we only find that such an increase would significantly reduce in 0.036 the number of visits to the emergency room over a two-year period. Among females of 60 years old (Table 20), we find that the reform would induce a reduction in 0.04 visits to the doctor and would induce an increase in 0.05 dental care visits over a two-year period.

\subsection{Subjective measures of health}

Table 21 reports the impacts of the reform in different measures of subjective well being for males such as self-perception of health, an indicator of difficulties in any daily activity, and indicators of difficulties in daily extenuating and basic activities, and self-reported life expectancy. The only notable result is that an increase of $\$ 100,000$ (US\$150) in expected pension wealth would induce an improvement of $3 \%$ in self-perception of good health, and a similar reduction in self-perception of bad health among males near retirement (60 years old). In the case of females, do not find statistically significant effects in any indicator, except for a not very robust decrease in $7 \%$ in difficulties in daily basic activities for females near retirement (age 55). Tables 25 and 26 show no significant impacts in self-reported probabilities of living at least until age 65 , or living until age 75 .

\subsection{Mental Health}

In addition to the subjective measures of health discussed before, in Tables 23 and 24 we include some measures of mental health that were only asked in 2009, but that were not followed-up in the 2012 survey round. Therefore, any change in these measures might represent a short-term impact of the reform on early takers of the new scheme. Table 23 reports some interesting results for this reduced sample of males. Among males near retirement (age 60), we find that an increase of $\$ 100,000$ (US\$150) in expected pension wealth would reduce self-reported probabilities of feeling depressed by $6 \%$, would reduce selfreported probabilities of feeling that everything they do implies an effort by $6 \%$, would increase the probability of feeling happy by $6 \%$, and would reduce the probability of feeling sad by $8.4 \%$. Table 24 reports the same results for females. However, in this case the induced changes, while moving in general in the same direction as males, are not statistically significant. 


\section{Concluding remarks}

In this paper, we study the effects on labor supply and well-being of a major reform introducing meanstested non-contributory pensions and incentives to contribute among workers the Chilean privately managed pension system in 2008. The new set of reforms were intended to guarantee a minimum level of consumption upon retirement, prevent old-age poverty and reduce gender inequalities, while at the same time provide the right incentives to increase the density of contributions. Targeted to individuals 65 years old or older living in households in the bottom $60 \%$ of the income distribution, the reform included a noncontributory welfare pension (the Pension Basica Solidaria, PBS) of US\$125/month, and a supplemental top-up (the Aporte Previsional Solidario, APS) for individuals with a low self-financed pension, which was phased-out as the private pension increased. Additional welfare measures targeted to reduce gender inequalities included bonuses for each child born, compensations upon divorce, and the implementation of survivorship pensions.

To investigate the effects of the reform on the outcomes of interest incorporating these mechanisms we adopted a version of the difference in differences estimator, using longitudinal data for the period 2004-2012 from the Social Protection Survey (Encuesta de Proteccion Social, EPS), which provides information about the different outcomes of study, merged with administrative records on pensions and contributions. We estimated the behavioral responses in labor supply, consumption, and well being outcomes respect to changes in expected pension wealth and accrual rates for individuals at different points in the life cycle for a sample of individuals facing retirement. We estimated expected pension wealth and accrual rates forecasting future contributions and wage profiles using the history of labor supply and contributions for each individual in our sample. To account for potential endogeneity of expected pension wealth and accrual rates, we used as instrumental variables the interactions of group dummies and year dummies reflecting the differential impact of the reform across different segments of the population.

Our preliminary results suggest that an increase of $\$ 100,000 \mathrm{clp}$ (US\$150) in expected pension wealth induced by the reform would not change labor market participation among males, bout would reduce female labor market participation by $3 \%$, due to a negative income effect. However, conditional on participation, changes in expected pension wealth induced by the reform would reduce labor informality among males and females, using different measures of informality such as contributing to the pension system, having a contract or self-employment rates. These changes are particularly larger among older individuals near retirement and are amplified by the effect of accrued pension wealth, demonstrating that the new incentives to contribute operate in the right direction. Our findings suggest that similar increase in pension wealth had a limited impact in other outcomes. We observe significant increases in aggregate household expenditures, in the number of dental care visits among females, and some improvements in subjective well being measures among males such as self-perceived health, feeling depressed, or feeling sad. However, we do not find significant impacts in more objective measures of physical health or in medical expenditures among males and females. Surprisingly, while most of the new reforms were targeted to females, we do not detect significant improvements in subjective well-being among them. While our results are only based on the sub-sample of individuals that were still not retired in 2008, where the reforms were implemented, the results in outcomes other than labor supply may change when we add to the sample the pool of individuals that were already retired in 2008 , and that were also benefited by the reforms. This analysis is work in progress. 


\section{References}

Attanasio, O., Meguir, C., and Otero, A. (2014). The Design of A Multitier Contributory Pension System: The Distributional Impact of the 2008 Chilean Pension Reform. Social Insurance, Informality and Labor Markets: How to Protect Workers While Creating Good Jobs.

Attanasio, O. P. and Brugiavini, A. (2003). Social security and households' saving. the Quarterly Journal of economics, pages 1075-1119.

Attanasio, O. P. and Rohwedder, S. (2003). Pension wealth and household saving: Evidence from pension reforms in the United Kingdom. American Economic Review, pages 1499-1521.

Behrman, J., Calderon, M. C., Mitchell, O. S., Vasquez, J., and Bravo, D. (2011). First-Round Impacts of the 2008 Chilean Pension System Reform. Michigan Retirement Research Center Research Paper No. WP, 245.

Campbell, A., Converse, P. E., and Rodgers, W. L. (1976). The quality of American life: Perceptions, evaluations, and satisfactions. Russell Sage Foundation.

Case, A. and Deaton, A. (1998). Large cash transfers to the elderly in South Africa. The Economic Journal, 108(450):1330-1361.

de Mesa, A. A., Bravo, D., Behrman, J. R., Mitchell, O. S., and Todd, P. E. (2006). The Chilean pension reform turns 25: lessons from the Social Protection Survey. Technical report, National Bureau of Economic Research.

Dethier, J.-J., Pestieau, P., and Ali, R. (2010). Universal minimum old age pensions: Impact on poverty and fiscal cost in 18 Latin American countries. World Bank Policy Research Working Paper Series, Vol.

Duflo, E. (2000). Child health and household resources in South Africa: Evidence from the Old Age Pension program. American Economic Review, pages 393-398.

Finkelstein, A., Taubman, S., Wright, B., Bernstein, M., Gruber, J., Newhouse, J. P., Allen, H., Baicker, K., and Others (2011). The Oregon health insurance experiment: evidence from the first year. Technical report, National Bureau of Economic Research.

Galiani, S., Gertler, P., and Bando, R. (2014). Non-contributory pensions. Technical report, National Bureau of Economic Research.

Heckman, J. and Singer, B. (1984). A Method for Minimizing the Impact of Distributional Assumptions in Econometric Models for Duration Data. Econometrica, 52(2):271-320.

Hubbard, R. G., Skinner, J., and Zeldes, S. P. (1994). Expanding the life-cycle model: Precautionary saving and public policy. The American Economic Review, 84(2):174-179.

Joubert, C. (2015). Pension design with a large informal labor market: Evidence from Chile. International Economic Review, 56(2):673-694.

Kay, S. J. and Kritzer, B. E. (2001). Social security in Latin America: recent reforms and challenges. Economic Review, (Q1):41-52. 
Lopez-Garcia, I. (2014). Human Capital and Labor Informality in Chile: A structural dynamic approach. RAND Working Papers.

Neumark, D. and Powers, E. (1998). The effect of means-tested income support for the elderly on pre-retirement saving: evidence from the SSI program in the U.S. Journal of Public Economics, 68:181-206.

Neumark, D. and Powers, E. (2000). Welfare for the elderly: the effects of SSI on pre- retirement labor supply. Journal of Public Economics, 78:51-80.

Walker, A. (2005). A European perspective on quality of life in old age. European Journal of Ageing, 2(1):2-12.

Ziliak, J. P. (2003). Income Transfers and Assets of the Poor. The Review of Economics and Statistics, 85(1):63-76. 


\section{Appendix}

\section{Descriptives Statistics}

\begin{tabular}{l|rr|rr}
\hline & \multicolumn{2}{|c|}{ Females } & \multicolumn{2}{c}{ Males } \\
& Non-pensioner & Pensioner & Non-pensioner & Pensioner \\
\hline \hline Low BMI (\%) & $23.1 \%$ & $21.1 \%$ & $17.5 \%$ & $17.4 \%$ \\
High BMI (\%) & $20.1 \%$ & $23.0 \%$ & $14.7 \%$ & $14.7 \%$ \\
Diagnosed of any disease, last two years & & & & \\
(\%) & $37.6 \%$ & $74.0 \%$ & $19.5 \%$ & $60.0 \%$ \\
Diagnosed asthma or emphysema & & & & \\
(respiratory problems) (\%) & $3.9 \%$ & $8.5 \%$ & $2.1 \%$ & $7.1 \%$ \\
Diagnosed depression (\%) & $12.2 \%$ & $15.4 \%$ & $2.9 \%$ & $5.4 \%$ \\
Diagnosed diabetes (\%) & $6.8 \%$ & $16.3 \%$ & $3.6 \%$ & $16.0 \%$ \\
Diagnosed hypertension or high blood & & & & \\
pressure (\%) & $18.8 \%$ & $51.7 \%$ & $10.0 \%$ & $39.4 \%$ \\
Diagnosed cardiac problems (\%) & $4.2 \%$ & $13.7 \%$ & $2.7 \%$ & $12.9 \%$ \\
Diagnosed arthritis or osteoarthritis (\%) & $7.6 \%$ & $28.1 \%$ & $1.9 \%$ & $10.0 \%$ \\
\hline
\end{tabular}

Table 9: Physical Health Outcomes over time, males and females

\begin{tabular}{lrr|rr}
\hline & \multicolumn{2}{c|}{ Females } & \multicolumn{2}{c}{ Males } \\
& Non-pensioner & Pensioner & Non-pensioner & Pensioner \\
\hline \hline Not under treatment but need it (\%) & $6.8 \%$ & $8.5 \%$ & $3.9 \%$ & $6.1 \%$ \\
OOP monthly expenditure in medicines (US & & & & \\
\$) & 28.3 & 43.3 & 20.3 & 26.8 \\
OOP expenditure in alternative medicine & & & & \\
last two years (US \$) & 4.8 & 8.3 & 1.9 & 5.3 \\
Out of pocket (OOP) expenditure last visit & & & & \\
to doctor (CLP \$) & 4.2 & 4.2 & 8.9 & 4.4 \\
Number visits to the doctor last two years & 5.9 & 9.3 & 2.4 & 7.4 \\
Number visits emergency room last two & & & & \\
years & 0.9 & 1.0 & 0.4 & 0.7 \\
Number dental care visits last two years & 1.0 & 0.7 & 0.6 & 0.5 \\
Number medical tests (laboratory. x-rays) & 1.9 & 2.6 & 0.7 & 2.0 \\
\hline
\end{tabular}

Table 10: Use and expenditures of medical services pensioners and non-pensioners, males and females

\begin{tabular}{lrr|rr}
\hline & \multicolumn{2}{c|}{ Females } & \multicolumn{2}{c}{ Males } \\
& Non-pensioner & Pensioner & Non-pensioner & Pensioner \\
\hline \hline Self-perception of good health (\%) & $63.4 \%$ & $33.3 \%$ & $76.1 \%$ & $41.3 \%$ \\
Self-perception of bad health (\%) & $36.6 \%$ & $66.6 \%$ & $23.8 \%$ & $58.7 \%$ \\
Difficulties in daily activities (\%) & $7.9 \%$ & $33.0 \%$ & $3.2 \%$ & $23.5 \%$ \\
Difficulties in daily extenuating & & & & \\
activities (\%) & $7.5 \%$ & $32.2 \%$ & $2.9 \%$ & $22.4 \%$ \\
Difficulties in daily basic activities (\%) & $2.3 \%$ & $11.0 \%$ & $1.0 \%$ & $8.3 \%$ \\
Probability of living until age 65 & 81.9 & 82.0 & 83.0 & 80.6 \\
Probability of living until age 75 & 77.7 & 78.3 & 77.5 & 79.7 \\
Probability of living until age 85 & 70.8 & 70.5 & 63.0 & 69.9 \\
Probabilility of living until age 100 & 51.4 & 56.8 & 49.4 & 50.4 \\
\hline
\end{tabular}

Table 11: Subjective well-being measures pensioners and non-pensioners, males and females 


\section{Impacts of the Reform}

\section{Labor Market Outcomes}

\begin{tabular}{|c|c|c|c|c|c|c|}
\hline \multirow[b]{2}{*}{ VARIABLES } & \multicolumn{4}{|c|}{ Labor Market Outcomes - Control Function Approach - Men } & \multirow[b]{2}{*}{$\begin{array}{c}\text { (5) } \\
\text { Formal Labor } \\
\text { Market } \\
\text { Participaction }\end{array}$} & \multirow[b]{2}{*}{$\begin{array}{c}\text { (6) } \\
\text { Contract Labor }\end{array}$} \\
\hline & $\begin{array}{l}\text { (1) } \\
\text { Labor Market } \\
\text { Participation }\end{array}$ & Unemployment & Self Employment & $\begin{array}{c}\text { (4) } \\
\text { Employers }\end{array}$ & & \\
\hline \multirow[t]{2}{*}{ Age } & $0.0525 * \bullet$ & $0.0913^{* * \bullet}$ & 0.0130 & 0.0265 & -0.0313 & -0.0366 \\
\hline & {$[0.0143]$} & {$[0.0184]$} & {$[0.0251]$} & {$[0.0270]$} & {$[0.0409]$} & {$[0.0272]$} \\
\hline \multirow[t]{2}{*}{ Age2 } & $-0.0006 * * 4$ & $-0.0011^{* * *}$ & $-0.0006^{* 4}$ & 0.0001 & 0.0004 & -0.0000 \\
\hline & [0.0002] & {$[0.0002]$} & {$[0.0003]$} & [0.0003] & {$[0.0005]$} & [0.0003] \\
\hline \multirow[t]{2}{*}{ Primary (1=Yes) } & $0.5258 * * *$ & $0.3317^{* * *}$ & $-0.3982^{* * *}$ & 0.0730 & -0.1648 & 0.0837 \\
\hline & {$[0.0527]$} & {$[0.0631]$} & {$[0.0827]$} & [0.0893] & {$[0.1390]$} & {$[0.0906]$} \\
\hline \multirow[t]{2}{*}{ Secondary(1=Yes) } & $0.9240^{* * *}$ & $0.6103^{* * 0}$ & $-0.6370^{* * 0}$ & $0.3296^{* 0}$ & -0.2667 & 0.2330 \\
\hline & {$[0.0981]$} & {$[0.1192]$} & [0.1549] & {$[0.1638]$} & {$[0.2485]$} & {$[0.1700]$} \\
\hline \multirow[t]{2}{*}{ Degree(1=Yes) } & $1.4237^{* 0 *}$ & $0.9945^{* * *}$ & $-0.9902^{* * *}$ & $0.5028^{\circ}$ & -0.5155 & 0.4828 \\
\hline & {$[0.1790]$} & {$[0.2189]$} & [0.2841] & {$[0.2960]$} & {$[0.4480]$} & {$[0.3097]$} \\
\hline \multirow[t]{2}{*}{ Married } & $-0.4866 * * *$ & $-0.5587^{* \cdots} \cdot$ & $0.2191^{* 0 *}$ & 0.0375 & $0.1787^{* * *}$ & $-0.0928 * * 0$ \\
\hline & {$[0.0190]$} & {$[0.0228]$} & {$[0.0302]$} & {$[0.0312]$} & {$[0.0468]$} & {$[0.0325]$} \\
\hline \multirow[t]{2}{*}{ Number Children 0-3 } & $-0.2536 * * 4$ & $-0.2121^{* \cdots}$ & $0.1482^{* 00}$ & $-0.1650^{* * 10}$ & -0.0105 & -0.0021 \\
\hline & {$[0.0220]$} & [0.0319] & [0.0393] & {$[0.0575]$} & {$[0.0729]$} & {$[0.0550]$} \\
\hline \multirow[t]{2}{*}{ Number Children 4-5 } & $-0.1403^{* * 1}$ & $-0.0839 * 0$ & $0.0796^{\circ}$ & 0.0179 & 0.0212 & $-0.0905^{*}$ \\
\hline & {$[0.0254]$} & {$[0.0350]$} & {$[0.0443]$} & {$[0.0520]$} & {$[0.0731]$} & {$[0.0545]$} \\
\hline \multirow[t]{2}{*}{ Number Children 6-13 } & $-0.0580^{* * 1 .}$ & $-0.0875^{* \cdots}$ & 0.0055 & $0.1419^{*}$ & 0.0190 & $-0.1047^{* 0 *}$ \\
\hline & {$[0.0168]$} & {$[0.0199]$} & {$[0.0263]$} & {$[0.0276]$} & {$[0.0414]$} & {$[0.0288]$} \\
\hline \multirow[t]{2}{*}{ Pension Wealth } & -0.0072 & -0.0003 & $-0.0174^{* *}$ & $-0.0232^{* 4}$ & 0.0098 & $0.0149^{* \bullet}$ \\
\hline & {$[0.0116]$} & {$[0.0104]$} & {$[0.0073]$} & {$[0.0101]$} & {$[0.0079]$} & {$[0.0070]$} \\
\hline \multirow[t]{2}{*}{ Pension Wealth * Age } & 0.0003 & $-0.0004^{*}$ & -0.0000 & $0.0008^{* 10}$ & 0.0002 & -0.0001 \\
\hline & {$[0.0002]$} & {$[0.0002]$} & {$[0.0001]$} & {$[0.0002]$} & {$[0.0002]$} & {$[0.0001]$} \\
\hline \multirow[t]{2}{*}{ Accrual Rate } & $-0.4153^{* * *}$ & $0.3011^{* 0 *}$ & $0.1166^{* *}$ & 0.0188 & $-1.5504^{* * 0}$ & $-0.2820 * 0$. \\
\hline & {$[0.0769]$} & {$[0.0563]$} & {$[0.0462]$} & {$[0.0411]$} & {$[0.0558]$} & {$[0.0391]$} \\
\hline \multirow[t]{2}{*}{ Accrual Rate*Age } & $0.0177^{* 0 *}$ & $-0.0126^{* \cdots}$ & $-0.0074^{* \cdots *}$ & -0.0011 & $0.0640^{\circ \cdots 4}$ & $0.0134^{* 0 *}$ \\
\hline & {$[0.0030]$} & [0.0019] & {$[0.0013]$} & {$[0.0012]$} & {$[0.0020]$} & {$[0.0012]$} \\
\hline Observations & 20,255 & 19,627 & 18,668 & 18,668 & 18,668 & 18,668 \\
\hline
\end{tabular}

Standard errors in brackets ${ }^{* *} \mathrm{p}<0.01,{ }^{* *} \mathrm{p}<0.05,{ }^{*} \mathrm{p}<0.1$, Pension Wealth variable is intrumented by dummes time and groups. Pension Wealth and Accrual Rate are measured in ch\$100000, respectively.

Table 12: Impacts of the reform in labor market outcomes - Men 
Labor Market Outcomes - Control Function Approach - Women

(1)

(2)

Labor Market Participation

Labor Market
Participation

Age 2

Primary $(1=$ Yes $)$

Secondary(1=Yes)

Degree(1=Yes)

Married

Number Children $0-3$

Number Children 4-5

Number Children 6-13

Pension Wealth

Pension Wealth * Age

Accrual Rate

Accrual Rate*Age

Observations

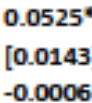

[0.0002]

$0.5258^{\circ * *}$

[0.0527]

$0.9240^{* * *}$

[0.0981]

$1.4237^{* * *}$

[0.1790]

$-0.4866^{* * *}$

[0.0190]

$-0.2536^{* * *}$

[0.0220]

$-0.1403^{* * *}$

[0.0254]

$-0.0580^{* * *}$

[0.0168]

$-0.0296^{* * *}$

[0.0073]

$-0.0001$

[0.0002]

$-2.2569^{\circ * *}$

[0.1102]

$0.0998^{* * *}$

[0.0041]
[0.0631]

$0.6103^{* 0 *}$

[0.2189]

$-0.5587^{\circ}$
$[0.0228]$

$-0.2121 * *$

[0.0319]

$-0.0839^{\circ}$

[0.0350]

$-0.0875^{* 0 *}$

[0.0199]

[0.0096]

$0.0007^{* * *}$

$[0.0002]$

$-0.0304^{*}$

18,551

13,448

Unemployment Self Employment

(3)

(4)

(5)

(6)

Formal Labor

Market Participaction

Contract Labor

Participaction

$-0.0313-0.0366$

$\begin{array}{lllll}{[0.0184]} & {[0.0251]} & {[0.0270]} & {[0.0409]} & {[0.0272]} \\ -0.0011^{* * *} & -0.0006^{* *} & 0.0001 & 0.0004 & -0.0000\end{array}$

$\begin{array}{lllll}{[0.0184]} & {[0.0251]} & {[0.0270]} & {[0.0409]} & {[0.0272]} \\ -0.0011^{* *} & -0.0006^{* *} & 0.0001 & 0.0004 & -0.0000\end{array}$

[0.0002] [0.0003] [0.0003]

$0.3317^{* 0 *}-0.3982^{* * *}$

[0.0827]

0.0730

[0.0005]

$-0.1648$

[0.0003]

0.0837

[0.0893]

[0.1390]

[0.0906]

$-0.6370^{\circ * *}$

$0.3296^{* 0}$

[0.1638]

$0.5028^{\circ}$

$-0.2667$

0.2330

[0.1192] [0.1549]

$0.9945^{* * *} \quad-0.9902^{* * *}$

[0.2485]

[0.1700]

[0.2841]

[0.2960]

0.0375

$0.2191^{\circ * *}$

[0.0312]

[0.0302]

$0.1482^{\circ 4 *}$

$-0.1650^{\circ}$.

[0.0393]

$0.0796^{\circ}$

[0.0443]

0.0055

[0.0263]

$0.0212^{* 0}$

[0.0575]

0.0179

[0.0520]

$0.1419^{* * *}$

[0.0276]

$0.0388^{* *}$

[0.0100]

[0.0152]

$-0.0003$

[0.0003]

[0.0002]

$0.3161^{\circ * *}$

$0.1404^{* *}$

$-0.5155$

0.4828

[0.4480]

[0.3097]

$0.1787^{* 0 *}$

$-0.0928 * 0 *$

[0.0468] [0.0325]

$-0.0105 \quad-0.0021$

$[0.0729] \quad[0.0550]$

$0.0212-0.0905^{*}$

[0.0731] [0.0545]

0.0190

[0.0414]

$-0.0493^{* 0 *}$

$-0.1047^{\circ *}$

[0.0288]

$-0.0390^{\circ * *}$

[0.0105]

$0.0014^{* * *}$

[0.0090]

$0.0013^{* 40}$

[0.0003]

[0.0002]

[0.0719] [0.0571]

$-0.0120^{* * *}$

[0.0576]

$-0.0041^{* *}$

$-3.5630^{\circ} \circ$

$-0.0451$

[0.1453]

$0.1564^{\circ *}$

[0.0633]

$0.0068^{\circ * \bullet}$

[0.0018]

[0.0057]

[0.0018]

11,495

11,495

11,495

11,495

Standard errors in brackets ** p<0.01, ${ }^{* *} \mathrm{p}<0.05,{ }^{*} \mathrm{p}<0.1$, Pension Wealth variable is intrumented by dummes time and groups. Pension Wealth and Accrual Rate are measured in Ch\$100000, respectively.

Table 13: Impacts of the reform in labor market outcomes - Women 


\section{Aggregate Expenditures}

Aggregate Household Expenditures - Control Function Approach

VARIABLES

\section{Age}

Age 2

Primary (1=Yes)

Secondary (1=Yes)

Degree(1=Yes)

Married

Number Children 0-3

Number Children 4-5

Number Children 6-13

Pension Wealth

Pension Wealth ${ }^{*}$ Age

Observations
(2)

$\mathrm{HH}$ expenditures in domestic help

-904.5860
$[1,571.7105]$
16.6536
$[18.5740]$
$4,888.2305$
$[4,802.2987]$
$3,391.7031$
$[8,919.7013]$
$-3,313.8185$
$[16,252.4825]$
$-8,986.0932$
$[5,916.7130]$
-777.7825
$[2,894.7626]$
$-2,219.5613$
$[3,219.6085]$
$-2,524.7847$
$[1,883.8755]$
71.5480
$[673.8595]$
$60.8022 * * *$
$[12.9134]$

-648.1502
$[414.5881]$
3.3635
$[4.9056]$
$4,842.3093^{* * *}$
$[1,267.9212]$
$9,764.7248^{* * *}$
$[2,359.8544]$
$10,677.6846^{* *}$
$[4,303.7848]$
$8,023.8041^{* * *}$
$[1,567.5426]$
$1,409.4051^{*}$
$[762.4023]$
$1,115.9518$
$[847.7846]$
$1,773.7373^{* * *}$
$[497.0149]$
-118.5547
$[178.5142]$
$27.3687^{* * *}$
$[3.4061]$

8,922
(3)

$\mathrm{HH}$ expenditures in transport

$$
\begin{gathered}
-1,230.3182 \\
{[769.6616]} \\
17.0947^{*} \\
{[9.1085]} \\
2,752.6414 \\
{[2,355.5475]} \\
5,840.2425 \\
{[4,374.1138]} \\
11,964.0475 \\
{[7,970.6841]} \\
-2,836.2633 \\
{[2,902.9561]} \\
-2,132.4631 \\
{[1,416.9096]} \\
-1,865.7182 \\
{[1,582.6269]} \\
-2,278.7891 * * \\
{[923.3400]} \\
420.8809 \\
{[331.6591]} \\
8.1415 \\
{[6.3353]}
\end{gathered}
$$

8,981

8,942
(4)

(5)

$\mathrm{HH}$ expenditures in utilities $\mathrm{HH}$ expenditures in (water, gas, phone, etc) clothing

$-1,098.3329^{*}$
$[602.8571]$
8.7492
$[7.1318]$
482.1371
$[1,850.2747]$
$1,983.2934$
$[3,434.8589]$
$6,473.1162$
$[6,259.1128]$
213.5864
$[2,278.0142]$
147.5795
$[1,109.4282]$
-529.7784
$[1,239.5793]$
799.0514
$[725.1985]$
-89.7460
$[259.5128]$
$11.0659 * *$
$[4.9651]$
8,881

Standard errors in brackets *** $p<0.01, * * p<0.05, * p<0.1$, Pension Wealth variable is intrumented by dummes time and groups. Pension Wealth is measured in Ch $\$ 100000$.

Table 14: Impacts of the reform in household aggregate expenditures 


\section{Self-care behaviors}

\begin{tabular}{|c|c|c|}
\hline \multicolumn{3}{|c|}{ Behaviors - Control Function Approach - Men } \\
\hline VARIABLES & $\begin{array}{c}\text { (1) } \\
\text { Practice sport at } \\
\text { least once a week } \\
(\%)\end{array}$ & $\begin{array}{c}\text { (2) } \\
\text { Alcohol current } \\
\text { use (\%) }\end{array}$ \\
\hline \multirow[t]{2}{*}{ Age } & $-0.0604^{* *}$ & -0.0327 \\
\hline & [0.0279] & [0.0243] \\
\hline \multirow[t]{2}{*}{ Age2 } & 0.0005 & 0.0002 \\
\hline & {$[0.0003]$} & {$[0.0003]$} \\
\hline \multirow[t]{2}{*}{ Primary (1=Yes) } & 0.1193 & -0.0103 \\
\hline & {$[0.0790]$} & {$[0.0436]$} \\
\hline \multirow{2}{*}{ Secondary(1=Yes) } & 0.2239 & 0.0167 \\
\hline & {$[0.1436]$} & [0.0512] \\
\hline \multirow[t]{2}{*}{ Degree(1=Yes) } & 0.2171 & 0.0009 \\
\hline & {$[0.2603]$} & {$[0.0586]$} \\
\hline \multirow[t]{2}{*}{ Married } & -0.0630 & $-0.1486^{* * *}$ \\
\hline & {$[0.0955]$} & {$[0.0361]$} \\
\hline \multirow[t]{2}{*}{ Number Children 0-3 } & 0.0136 & -0.0159 \\
\hline & {$[0.0418]$} & {$[0.0416]$} \\
\hline \multirow[t]{2}{*}{ Number Children 4-5 } & 0.0116 & -0.0115 \\
\hline & {$[0.0467]$} & [0.0459] \\
\hline \multirow[t]{2}{*}{ Number Children 6-13 } & 0.0209 & 0.0342 \\
\hline & {$[0.0308]$} & {$[0.0223]$} \\
\hline \multirow[t]{2}{*}{ Pension Wealth } & 0.0022 & \\
\hline & {$[0.0108]$} & \\
\hline \multirow[t]{2}{*}{ Pension Wealth*Age } & -0.0000 & \\
\hline & {$[0.0002]$} & \\
\hline Observations & 6,728 & 6,728 \\
\hline
\end{tabular}

Standard errors in brackets ${ }^{* * *} p<0.01,{ }^{* *} p<0.05,{ }^{*} p<0.1$, Pension Wealth variable is intrumented by dummes time and groups. Pension Wealth is measured in $\mathrm{Ch} \$ 100000$.

Table 15: Impacts of the reform in self-care behaviors - Men 
Behaviors - Control Function Approach - Women

(1)

(2)

Practice sport at

VARIABLES least once a week

Alcohol current (\%) use (\%)

\begin{tabular}{|c|c|c|}
\hline \multirow{2}{*}{ Age } & $-0.0892^{* * *}$ & -0.0224 \\
\hline & [0.0333] & [0.0307] \\
\hline \multirow{2}{*}{ Age2 } & $0.0008^{* *}$ & 0.0000 \\
\hline & {$[0.0004]$} & {$[0.0004]$} \\
\hline \multirow[t]{2}{*}{ Primary (1=Yes) } & 0.1237 & 0.0778 \\
\hline & {$[0.1151]$} & [0.1017] \\
\hline \multirow[t]{2}{*}{ Secondary(1=Yes) } & -0.0663 & 0.2137 \\
\hline & {$[0.2081]$} & [0.1849] \\
\hline \multirow[t]{2}{*}{ Degree(1=Yes) } & -0.1058 & 0.4938 \\
\hline & [0.3753] & [0.3354] \\
\hline \multirow[t]{2}{*}{ Married } & 0.0360 & $-0.1598 * * *$ \\
\hline & {$[0.0416]$} & [0.0377] \\
\hline \multirow[t]{2}{*}{ Number Children 0-3 } & $-0.0988^{*}$ & -0.0733 \\
\hline & {$[0.0521]$} & [0.0464] \\
\hline \multirow[t]{2}{*}{ Number Children 4-5 } & -0.0524 & -0.0738 \\
\hline & [0.0557] & {$[0.0503]$} \\
\hline \multirow[t]{2}{*}{ Number Children 6-13 } & -0.0279 & 0.0462 \\
\hline & {$[0.0362]$} & [0.0323] \\
\hline \multirow[t]{2}{*}{ Pension Wealth } & 0.0057 & -0.0176 \\
\hline & {$[0.0130]$} & [0.0115] \\
\hline \multirow[t]{2}{*}{ Pension Wealth*Age } & 0.0004 & 0.0001 \\
\hline & [0.0003] & [0.0003] \\
\hline Observations & 6,131 & 6,131 \\
\hline
\end{tabular}

Standard errors in brackets $* * * \mathrm{p}<0.01,{ }^{* *} \mathrm{p}<0.05,{ }^{*} \mathrm{p}<0.1$, Pension Wealth variable is intrumented by dummes time and groups. Pension Wealth is measured in Ch\$100000.

Table 16: Impacts of the reform in self-care behaviors - Women 
Objective Measures of Physical Health

Phygical Health Outcomes - Control Function Approach - Men

(1)

[2]

[3]

[4]

[5]

[6]

Diagnosed

Diagnosed of any asthma or

VARIABLES

Low BMI [\$] High BMI (\$) disease, last two emphysema

years (\$)

(respiratory problems] [\%

Age

Age2

Primary [1=Yes]

Secondary (1=Yes)

Degree(1=Yes)

Married

Number Children 0-3

Number Children 4-5

Number Children 6-13

Pension Wealth

Pension Wealth"Age

Observations

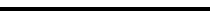

$\begin{array}{lll}0.0152 & -0.0655^{* *} & -0.0042 \\ {[0.0332]} & {[0.0262]} & {[0.0509]} \\ -0.0001 & 0.0011^{* \cdots} & 0.0002 \\ {[0.0004]} & {[0.0003]} & {[0.0006]} \\ 0.0138 & -0.0453 & 0.0275\end{array}$

$-0.1161^{21.4}$
$[0.0431]$
$0.0012^{* 4}$

$-0.0674^{\cdots 4}$

[0.0315]

[0.0004]

0.0138

$\begin{array}{ll}-0.1377 & 0.0138 \\ {[0.0893]} & {[0.0900]}\end{array}$

[0.0780]

$-0.0444$

$-0.0057$

[0.1621]

0.1226

[0.0005]

[0.0529]

0.0003

0.1900

[0.1354]

[0.1473]

$\begin{array}{ll}-0.2298 & -0.0444 \\ {[0.1637]} & {[0.1653]}\end{array}$

[0.1473]

[0.3019]

$-0.1372$

$\begin{array}{ll}-0.3280 & -0.0547 \\ {[0.2967]} & {[0.2994]}\end{array}$

[0.2704]

0.4181

[0.5459]

[0.2515]

0.4022

[0.2864]

$-0.2912^{* 14} \quad 0.1345$

[D.1099] [0.1100]

$-0.0030$

$0.0058 \quad-0.0477$

[0.0486] [0.0515]

$-0.0323 \quad-0.0003$

[0.0564]

[0.0554]

$-0.0504$

[0.0357]

[0.0356]

0.0156

$-0.0086$

[0.0124]

$[0.0003]$

[0.0124]

$-0.0003$

[0.0981]

0.1408

[0.2013]

[0.4586]

0.5448

0.0330

[0.0585] [0.1110]

$-0.0542^{*} \quad-0.0599$

[0.0313] [0.0669]

$0.0011 \quad-0.0025$

[0.0113]

0.0001

[0.0228]

$-0.0003$

[0.0818]

[0.0861]

0.0197

[0.0531]

$-0.0073$

[0.0188]

0.0005

[0.1153]

$-0.0006$

[0.0004]

[0.0004]

9,098

9,098

9,098

(5)

Diagnosed
depression $(\%) \quad$ diagnosed
diabetes $(\%)$

(7)

[8]

[9]

\begin{tabular}{ccc}
$\begin{array}{c}\text { Diagnosed } \\
\text { hypertension or } \\
\text { high blood } \\
\text { pressure }(\%)\end{array}$ & $\begin{array}{c}\text { Diagnosed } \\
\text { cardiac problems }\end{array}$ & $\begin{array}{c}\text { Diagnosed } \\
\text { sithritis or } \\
\text { osteosithritis }\left(\%_{0}\right)\end{array}$ \\
\hline
\end{tabular}

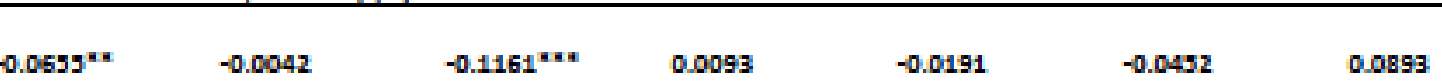

$-0.0452 \quad 0.0893$

[0.0343]

0.0005

[0.0489]

[0.0708]

$[0.0004]$

$-0.0856$

0.0005

$-0.0006$

[0.0966]

[0.0005]

[0.0007]

$-0.0492$

[0.1870]

0.1580

0.0641

[0.1824]

$0.2711 \quad 0.2055$

$\begin{array}{ll}0.2711 & 0.2055 \\ {[0.2722]} & {[0.3558]}\end{array}$

$0.1783 \quad-0.0185$

$\begin{array}{lll}-0.1790 & 0.1783 & -0.018] \\ {[0.3468]} & {[0.9010]} & {[0.6702]}\end{array}$

$\begin{array}{llll}{[0.5324]} & {[0.3468]} & {[0.5010]} & {[0.6702]} \\ 0.0645 & 0.0799 & 0.1933 & 0.2633\end{array}$

$\begin{array}{llll}{[0.1898]} & {[0.1248]} & {[0.1834]} & {[0.2385]} \\ -0.3139^{* 1} & -0.1808^{* *} & -0.1061 & -0.0845\end{array}$

$\begin{array}{llll}{[0.1898]} & {[0.1248]} & {[0.1834]} & {[0.2385]} \\ -0.3139^{* *} & -0.1808 * \mathrm{~N} & -0.1061 & -0.0845\end{array}$

$\left[\begin{array}{llll}{[0.1557]} & {[0.0767]} & {[0.1101]}\end{array}\right]$

$-0.1072$

$-0.3218^{* *}$

$-0.2654$

$\left.\begin{array}{llll}0.1193] & {[0.0778]} & {[0.1621]} & {[0.2022]}\end{array}\right]$

$\begin{array}{llll}0.0198 & -0.0523 & -0.0790 & -0.0112\end{array}$

$\left[\begin{array}{llll}0.0591] & {[0.0393]} & {[0.0626]} & {[0.0753]}\end{array}\right.$

$\begin{array}{llll}0.0061 & 0.0032 & -0.0085 & -0.0259\end{array}$

$\left[\begin{array}{llll}{[0.0224]} & {[0.0145]} & {[0.0206]} & {[0.0279]}\end{array}\right]$

0.0001

$-0.0001$

[0.0279]

9,098

9,098

9,098

Standard errors in brackets $\cdots *$ pe0.01, $\cdots$ pe0.05, " pe0.1, Pension Wealth variable is intrumented by dummes time and groups. Pension Weath and Accrual Rate is measured in Ch\$100000.

Table 17: Impacts of the reform in objective health outcomes - Men 
Physical Health Outcomes - Control Function Approsch - Women

[2]

(3)

[5]

Diagnosed

VARIABLES

Low BMI [\$] High BMI (\%) $\begin{aligned} & \text { Diagnosed of any } \\ & \text { disease, last two }\end{aligned}$ years [\%]

asthma or

emphysems

(respiratory problems] (3)]
[6]
[7]

[8]

[9]

\begin{tabular}{|c|c|c|c|c|c|c|c|c|c|}
\hline & & & yesrs $[\$]$ & $\begin{array}{l}\text { (respiratory } \\
\text { problems] (*;) }\end{array}$ & depression ( $\left.x_{1}\right)$ & diabetes $\left(\gamma_{0}\right)$ & $\begin{array}{l}\text { nght blood } \\
\text { pressure (\$) }\end{array}$ & $(\$)$ & osteosrthritis $(\$ \mathrm{~s})$ \\
\hline \multirow[t]{2}{*}{ Age } & -0.0285 & 0.0300 & 0.0380 & -0.0589 & $0.0540^{*}$ & $0.0742^{*}$ & $0.1061^{2 \ldots x}$ & $-0.0935^{2 x}$ & $0.1012^{*}$ \\
\hline & {$[0.0316]$} & {$[0.0342]$} & {$[0.0245]$} & {$[0.0449]$} & {$[0.0297]$} & [0.0435] & {$[0.0324]$} & {$[0.0451]$} & {$[0.0536]$} \\
\hline \multirow[t]{2}{*}{ Age2 } & 0.0002 & -0.0003 & 0.0001 & 0.0006 & -0.0003 & -0.0004 & -0.0005 & $0.0015 \times 1 \times$ & -0.0004 \\
\hline & {$[0.0004]$} & {$[0.0004]$} & {$[0.0003]$} & [0.0005] & {$[0.0003]$} & {$[0.0005]$} & {$[0.0004]$} & {$[0.0005]$} & {$[0.0006]$} \\
\hline \multirow[t]{2}{*}{ Primary [1=Yes] } & 0.0013 & -0.0401 & 0.1341 & -0.1902 & 0.0816 & 0.1915 & $0.2465 * 4$ & -0.0274 & -0.0834 \\
\hline & {$[0.1071]$} & {$[0.1083]$} & {$[0.0860]$} & {$[0.1581]$} & {$[0.1035]$} & {$[0.1414]$} & {$[0.1062]$} & {$[0.1664]$} & {$[0.1564]$} \\
\hline \multirow[t]{2}{*}{ Secondary (1=Yes) } & 0.1799 & -0.2402 & 0.1363 & -0.2935 & 0.0870 & 0.4085 & 0.2820 & -0.2041 & -0.1179 \\
\hline & {$[0.1932]$} & {$[0.2029]$} & {$[0.1605]$} & {$[0.2986]$} & {$[0.1944]$} & {$[0.2709]$} & {$[0.2022]$} & {$[0.3137]$} & {$[0.3111]$} \\
\hline \multirow[t]{2}{*}{ Degree(1=Yes) } & 0.3811 & -0.2915 & 0.4519 & 0.0030 & 0.2292 & $0.8823^{*}$ & 0.6028 & -0.3160 & -0.0191 \\
\hline & {$[0.3491]$} & {$[0.3692]$} & [0.2929] & [0.5375] & {$[0.3547]$} & {$[0.4946]$} & {$[0.3709]$} & [0.5698] & {$[0.5743]$} \\
\hline \multirow[t]{2}{*}{ Married } & $-0.2077^{214}$ & $0.1397^{* 2 x}$ & 0.0043 & -0.0173 & $-0.1167^{\cdots 12}$ & $0.1293^{211}$ & 0.0612 & $0.1036^{*}$ & -0.0458 \\
\hline & {$[0.0396]$} & {$[0.0401]$} & {$[0.0311]$} & {$[0.0587]$} & {$[0.0377]$} & {$[0.0494]$} & {$[0.0373]$} & {$[0.0597]$} & {$[0.0521]$} \\
\hline \multirow[t]{2}{*}{ Number Children 0-3 } & 0.0288 & -0.0511 & -0.0360 & -0.0517 & -0.0177 & -0.0828 & -0.0051 & 0.1049 & -0.0439 \\
\hline & {$[0.0466]$} & {$[0.0532]$} & {$[0.0458]$} & {$[0.0930]$} & {$[0.0561]$} & [0.0893] & {$[0.0626]$} & {$[0.0838]$} & {$[0.1197]$} \\
\hline \multirow[t]{2}{*}{ Number Children 4-5 } & 0.0078 & -0.0265 & -0.0504 & -0.0488 & -0.0123 & -0.0955 & -0.0395 & -0.0924 & 0.0447 \\
\hline & {$[0.0511]$} & {$[0.0565]$} & {$[0.0501]$} & {$[0.1023]$} & {$[0.0601]$} & [0.0953] & {$[0.0679]$} & {$[0.1104]$} & {$[0.1170]$} \\
\hline \multirow[t]{2}{*}{ Number Children 6-13 } & -0.0006 & -0.0019 & $0.0519^{*}$ & 0.0197 & $0.0672^{24}$ & 0.0744 & 0.0455 & -0.0358 & $-0.1113^{*}$ \\
\hline & {$[0.0337]$} & {$[0.0354]$} & {$[0.0277]$} & {$[0.0527]$} & {$[0.0338]$} & [0.0463] & {$[0.0350]$} & {$[0.0554]$} & {$[0.0577]$} \\
\hline \multirow[t]{2}{*}{ Pension Wealth } & 0.0023 & 0.0101 & $-0.0177^{*}$ & 0.0062 & -0.0075 & -0.0064 & -0.0200 & 0.0286 & -0.0097 \\
\hline & {$[0.0120]$} & {$[0.0125]$} & [0.0103] & [0.0191] & {$[0.0123]$} & {$[0.0174]$} & {$[0.0130]$} & [0.0199] & {$[0.0209]$} \\
\hline \multirow[t]{2}{*}{ Pension Wealth"Age } & -0.0002 & -0.0003 & -0.0002 & -0.0001 & -0.0002 & $-0.0008^{* x}$ & -0.0003 & -0.0003 & -0.0000 \\
\hline & {$[0.0003]$} & {$[0.0003]$} & {$[0.0002]$} & {$[0.0004]$} & {$[0.0003]$} & {$[0.0004]$} & {$[0.0003]$} & {$[0.0004]$} & {$[0.0004]$} \\
\hline Observations & 6,131 & 6,131 & 8,333 & 8,333 & 8,333 & 8,333 & 8,333 & 8,333 & 8,333 \\
\hline
\end{tabular}

Standard errors in brackets ** pe0.01, “ pe0.05, " p-0.1, Pension Wealth variable is intrumented by dummes time and groups. Pension Weaith and Accrual Rate is measured in Ch\$100000.

Table 18: Impacts of the reform in objective health outcomes - Women 


\section{Medical Expenditures}

Medical Expenditures Outcomes - Control Function Approach - Men

(1)

(2)

(3)

(4)

(5)

Not under Number visits Number visits Number Number VARIABLES treatment but to the doctor emergency dental care medical tests need it (\%) last two years room last two visits last two (laboratory. $\mathrm{x}$ -

\begin{tabular}{|c|c|c|c|c|c|}
\hline \multirow[t]{2}{*}{ Age } & -0.0450 & $-0.0588^{* *}$ & -0.0285 & -0.0388 & $-0.0538^{*}$ \\
\hline & {$[0.0408]$} & {$[0.0271]$} & {$[0.0312]$} & {$[0.0330]$} & {$[0.0317]$} \\
\hline \multirow[t]{2}{*}{ Age2 } & 0.0007 & $0.0008^{\bullet \bullet}$ & 0.0003 & 0.0005 & $0.0009^{\bullet \bullet}$ \\
\hline & {$[0.0005]$} & {$[0.0003]$} & {$[0.0004]$} & {$[0.0004]$} & {$[0.0004]$} \\
\hline \multirow[t]{2}{*}{ Primary (1=Yes) } & $-0.2221^{*}$ & 0.1180 & 0.0553 & $0.1677^{*}$ & $0.2422 \cdots$ \\
\hline & {$[0.1223]$} & {$[0.0751]$} & {$[0.0869]$} & {$[0.0948]$} & {$[0.0876]$} \\
\hline \multirow[t]{2}{*}{ Secondary(1=Yes) } & -0.3506 & 0.2211 & 0.1786 & $0.3611^{* *}$ & $0.3160^{\bullet}$ \\
\hline & {$[0.2366]$} & {$[0.1374]$} & {$[0.1586]$} & {$[0.1676]$} & {$[0.1564]$} \\
\hline \multirow[t]{2}{*}{ Degree(1=Yes) } & $-0.7572^{\bullet}$ & 0.3839 & 0.1458 & $0.5903^{* *}$ & 0.4495 \\
\hline & {$[0.4382]$} & {$[0.2483]$} & {$[0.2862]$} & {$[0.3007]$} & {$[0.2802]$} \\
\hline \multirow[t]{2}{*}{ Married } & -0.1506 & 0.1438 & 0.1196 & -0.0241 & 0.1499 \\
\hline & {$[0.1587]$} & {$[0.0912]$} & {$[0.1054]$} & {$[0.1106]$} & {$[0.1027]$} \\
\hline \multirow[t]{2}{*}{ Number Children 0-3 } & -0.0238 & $-0.0739^{*}$ & 0.0132 & 0.0713 & 0.0349 \\
\hline & {$[0.0771]$} & {$[0.0417]$} & {$[0.0470]$} & {$[0.0489]$} & {$[0.0490]$} \\
\hline \multirow[t]{2}{*}{ Number Children 4-5 } & $-0.1922^{*}$ & 0.0398 & 0.0136 & -0.0569 & -0.0554 \\
\hline & [0.0999] & {$[0.0454]$} & {$[0.0521]$} & {$[0.0573]$} & {$[0.0542]$} \\
\hline \multirow[t]{2}{*}{ Number Children 6-13 } & -0.0521 & -0.0369 & 0.0141 & 0.0124 & -0.0272 \\
\hline & {$[0.0493]$} & {$[0.0295]$} & [0.0339] & {$[0.0363]$} & [0.0339] \\
\hline \multirow[t]{2}{*}{ Pension Wealth } & 0.0173 & 0.0002 & 0.0113 & 0.0014 & $0.0191^{*}$ \\
\hline & {$[0.0180]$} & {$[0.0104]$} & {$[0.0118]$} & {$[0.0127]$} & {$[0.0116]$} \\
\hline \multirow[t]{2}{*}{ Pension Wealth"Age } & -0.0001 & 0.0001 & $-0.0006^{* *}$ & -0.0000 & -0.0004 \\
\hline & {$[0.0004]$} & {$[0.0002]$} & {$[0.0003]$} & {$[0.0003]$} & {$[0.0002]$} \\
\hline Observations & 9,098 & 6,728 & 6,728 & 6,728 & 6,728 \\
\hline
\end{tabular}

Standard errors in brackets *** $p<0.01, \cdots p<0.05, * p<0.1$, Pension Wealth variable is intrumented by dummes time and groups. Pension Wealth and Accrual Rate is measured in Ch\$100000.

Table 19: Impacts of the reform in medical expenditures - Men 
Medical Expenditures Outcomes - Control Function Approach - Women

(1)

(2)

(3)

(4)

(5)

\begin{tabular}{|c|c|c|c|c|c|}
\hline VARIABLES & $\begin{array}{l}\text { Not under } \\
\text { treatment but } \\
\text { need it (\%) }\end{array}$ & $\begin{array}{l}\text { Number visits } \\
\text { to the doctor } \\
\text { last two years }\end{array}$ & $\begin{array}{c}\text { Number visits } \\
\text { emergency } \\
\text { room last two } \\
\text { years }\end{array}$ & $\begin{array}{c}\text { Number } \\
\text { dental care } \\
\text { visits last two } \\
\text { years }\end{array}$ & $\begin{array}{c}\text { Number } \\
\text { medical tests } \\
\text { (laboratory. x- } \\
\text { rays) }\end{array}$ \\
\hline \multirow[t]{2}{*}{ Age } & 0.0588 & $-0.0847^{* * *}$ & -0.0037 & -0.0325 & -0.0413 \\
\hline & {$[0.0377]$} & {$[0.0301]$} & {$[0.0316]$} & {$[0.0311]$} & {$[0.0295]$} \\
\hline Age2 & $\begin{array}{c}-0.0003 \\
{[0.0004]}\end{array}$ & $\begin{array}{c}0.0012^{* * *} \\
{[0.0004]}\end{array}$ & $\begin{array}{c}0.0001 \\
{[0.0004]}\end{array}$ & $\begin{array}{c}0.0002 \\
{[0.0004]}\end{array}$ & $\begin{array}{c}0.0006 \\
{[0.0004]}\end{array}$ \\
\hline Primary (1=Yes) & $\begin{array}{l}-0.1839 \\
{[0.1254]}\end{array}$ & $\begin{array}{c}0.3230^{* * *} \\
{[0.0984]}\end{array}$ & $\begin{array}{c}0.0593 \\
{[0.1030]}\end{array}$ & $\begin{array}{l}-0.0107 \\
{[0.1038]}\end{array}$ & $\begin{array}{c}0.1563 \\
{[0.0963]}\end{array}$ \\
\hline Secondary(1=Yes) & $\begin{array}{l}-0.3640 \\
{[0.2384]}\end{array}$ & $\begin{array}{c}0.4405^{* *} \\
{[0.1811]}\end{array}$ & $\begin{array}{c}0.1152 \\
{[0.1894]}\end{array}$ & $\begin{array}{c}-0.0147 \\
{[0.1869]}\end{array}$ & $\begin{array}{c}0.2674 \\
{[0.1756]}\end{array}$ \\
\hline Degree(1=Yes) & $\begin{array}{l}-0.5120 \\
{[0.4368]}\end{array}$ & $\begin{array}{c}0.7617^{* *} \\
{[0.3295]}\end{array}$ & $\begin{array}{c}0.1796 \\
{[0.3439]}\end{array}$ & $\begin{array}{c}0.0144 \\
{[0.3376]}\end{array}$ & $\begin{array}{l}0.5239^{*} \\
{[0.3171]}\end{array}$ \\
\hline Married & $\begin{array}{l}-0.0275 \\
{[0.0462]}\end{array}$ & $\begin{array}{c}0.1316^{* * *} \\
{[0.0364]}\end{array}$ & $\begin{array}{c}0.0544 \\
{[0.0382]}\end{array}$ & $\begin{array}{c}0.0450 \\
{[0.0383]}\end{array}$ & $\begin{array}{c}0.1751^{* * *} \\
{[0.0355]}\end{array}$ \\
\hline Number Children 0-3 & $\begin{array}{c}0.0572 \\
{[0.0665]}\end{array}$ & $\begin{array}{c}-0.0250 \\
{[0.0445]}\end{array}$ & $\begin{array}{c}-0.0146 \\
{[0.0481]}\end{array}$ & $\begin{array}{c}-0.0694 \\
{[0.0479]}\end{array}$ & $\begin{array}{c}-0.0033 \\
{[0.0448]}\end{array}$ \\
\hline Number Children 4-5 & $\begin{array}{l}-0.1318^{*} \\
{[0.0796]}\end{array}$ & $\begin{array}{c}-0.0090 \\
{[0.0485]}\end{array}$ & $\begin{array}{c}0.0224 \\
{[0.0510]}\end{array}$ & $\begin{array}{c}-0.0852 \\
{[0.0520]}\end{array}$ & $\begin{array}{c}-0.1071^{* *} \\
{[0.0489]}\end{array}$ \\
\hline Number Children 6-13 & $\begin{array}{c}0.0434 \\
{[0.0409]}\end{array}$ & $\begin{array}{c}0.0226 \\
{[0.0315]}\end{array}$ & $\begin{array}{c}0.0676^{* *} \\
{[0.0331]}\end{array}$ & $\begin{array}{l}-0.0330 \\
{[0.0330]}\end{array}$ & $\begin{array}{l}-0.0103 \\
{[0.0310]}\end{array}$ \\
\hline Pension Wealth & $\begin{array}{c}0.0069 \\
{[0.0151]}\end{array}$ & $\begin{array}{c}0.0086 \\
{[0.0114]}\end{array}$ & $\begin{array}{c}-0.0207^{*} \\
{[0.0117]}\end{array}$ & $\begin{array}{l}-0.0104 \\
{[0.0117]}\end{array}$ & $\begin{array}{l}-0.0012 \\
{[0.0108]}\end{array}$ \\
\hline Pension Wealth ${ }^{*}$ Age & $\begin{array}{c}0.0001 \\
{[0.0003]}\end{array}$ & $\begin{array}{c}-0.0007^{\bullet \cdots} \\
{[0.0003]}\end{array}$ & $\begin{array}{c}0.0001 \\
{[0.0003]}\end{array}$ & $\begin{array}{c}0.0008^{* * *} \\
{[0.0003]}\end{array}$ & $\begin{array}{l}-0.0002 \\
{[0.0003]}\end{array}$ \\
\hline Observations & 8,333 & 6,131 & 6,131 & 6,131 & 6,131 \\
\hline
\end{tabular}

Standard errors in brackets $* * * 00.01, * * p<0.05, * p<0.1$, Pension Wealth variable is intrumented by dummes time and groups. Pension Wealth and Accrual Rate is measured in Ch\$100000.

Table 20: Impacts of the reform in medical expenditures - Women 


\section{Subjective Measures of Health}

\begin{tabular}{|c|c|c|c|c|c|}
\hline \multicolumn{6}{|c|}{ Subjective Well being - Control Function Approach - Men } \\
\hline VARIABLES & $\begin{array}{l}\text { (1) } \\
\text { Self-perception of } \\
\text { good health (\%) }\end{array}$ & $\begin{array}{l}\text { (2) } \\
\text { Self-perception of } \\
\text { bad health (\%) }\end{array}$ & $\begin{array}{l}\text { (3) } \\
\text { Difficulties in daily } \\
\text { activities (\%) }\end{array}$ & $\begin{array}{c}\text { (4) } \\
\text { Difficulties in daily } \\
\text { extenuating } \\
\text { activities (\%) }\end{array}$ & $\begin{array}{l}\text { (5) } \\
\text { Difficulties in daily } \\
\text { basic activities (\%) }\end{array}$ \\
\hline \multirow{2}{*}{ Age } & 0.0059 & -0.0061 & -0.0541 & -0.0187 & -0.1210 \\
\hline & {$[0.0250]$} & {$[0.0250]$} & {$[0.0515]$} & [0.0555] & {$[0.0795]$} \\
\hline \multirow[t]{2}{*}{ Age2 } & -0.0002 & 0.0002 & 0.0007 & 0.0003 & 0.0011 \\
\hline & [0.0003] & [0.0003] & {$[0.0006]$} & [0.0006] & {$[0.0009]$} \\
\hline \multirow[t]{2}{*}{ Primary (1=Yes) } & $0.2533^{* * * *}$ & $-0.2522 * * *$ & -0.1816 & -0.1131 & -0.1922 \\
\hline & {$[0.0736]$} & {$[0.0736]$} & {$[0.1508]$} & {$[0.1587]$} & {$[0.2377]$} \\
\hline \multirow[t]{2}{*}{ Secondary(1=Yes) } & $0.4928 * * *$ & $-0.4922 * * *$ & -0.3581 & -0.3118 & -0.3691 \\
\hline & {$[0.1408]$} & {$[0.1408]$} & {$[0.2920]$} & [0.3103] & [0.4534] \\
\hline \multirow[t]{2}{*}{ Degree(1=Yes) } & $0.9325^{* * * *}$ & $-0.9327^{* * * *}$ & -0.6672 & -0.4440 & -0.9863 \\
\hline & {$[0.2610]$} & {$[0.2610]$} & [0.5407] & {$[0.5737]$} & [0.8614] \\
\hline \multirow[t]{2}{*}{ Married } & 0.0266 & -0.0280 & -0.1448 & -0.0021 & -0.3966 \\
\hline & [0.0941] & [0.0941] & [0.1952] & [0.2080] & [0.3060] \\
\hline \multirow[t]{2}{*}{ Number Children 0-3 } & 0.0321 & -0.0315 & -0.0808 & -0.0810 & -0.1148 \\
\hline & [0.0481] & [0.0481] & {$[0.1260]$} & [0.1374] & [0.1985] \\
\hline \multirow[t]{2}{*}{ Number Children 4-5 } & 0.0290 & -0.0288 & -0.0478 & -0.1123 & -0.0787 \\
\hline & [0.0533] & [0.0533] & {$[0.1264]$} & {$[0.1518]$} & [0.1924] \\
\hline \multirow[t]{2}{*}{ Number Children 6-13 } & 0.0442 & -0.0437 & -0.0871 & -0.0990 & -0.0186 \\
\hline & {$[0.0297]$} & {$[0.0297]$} & {$[0.0627]$} & {$[0.0680]$} & {$[0.0961]$} \\
\hline \multirow[t]{2}{*}{ Pension Wealth } & 0.0150 & -0.0150 & 0.0201 & 0.0082 & -0.0019 \\
\hline & {$[0.0107]$} & {$[0.0107]$} & [0.0219] & {$[0.0234]$} & [0.0334] \\
\hline \multirow[t]{2}{*}{ Pension Wealth*Age } & $0.0005^{* *}$ & $-0.0005^{* *}$ & 0.0000 & 0.0000 & 0.0007 \\
\hline & {$[0.0002]$} & {$[0.0002]$} & [0.0004] & [0.0004] & {$[0.0007]$} \\
\hline Observations & 9,098 & 9,098 & 9,098 & 9,098 & 9,098 \\
\hline
\end{tabular}

Standard errors in brackets *** $p<0.01, * * p<0.05, * p<0.1$, Pension Wealth variable is intrumented by dummes time and groups. Pension Wealth and Accrual Rate is measured in Ch\$100000.

Table 21: Impacts of the reform in subjective health - Men 
Subjective Well being - Control Function Approach - Women
(1)
(2)
(3)
(4)
(5)

VARIABLES

Self-perception of Self-perception of Difficulties in

Difficulties in good health (\%) bad health (\%) daily activities (\%) daily extenuating

Difficulties in daily

basic activities (\%)

\begin{tabular}{|c|c|c|c|c|c|}
\hline Age & $\begin{array}{c}-0.0581^{* *} \\
{[0.0246]}\end{array}$ & $\begin{array}{l}0.0602^{* *} \\
{[0.0246]}\end{array}$ & $\begin{array}{c}0.0560 \\
{[0.0450]}\end{array}$ & $\begin{array}{c}0.0660 \\
{[0.0470]}\end{array}$ & $\begin{array}{c}0.2128^{* *} \\
{[0.0889]}\end{array}$ \\
\hline Age2 & 0.0003 & -0.0004 & -0.0003 & -0.0004 & $-0.0017^{*}$ \\
\hline & {$[0.0003]$} & {$[0.0003]$} & {$[0.0005]$} & {$[0.0005]$} & [0.0009] \\
\hline Primary (1=Yes) & $\begin{array}{c}0.2544^{* * *} \\
{[0.0860]}\end{array}$ & $\begin{array}{c}-0.2486^{* * *} \\
{[0.0860]}\end{array}$ & $\begin{array}{l}-0.1996 \\
{[0.1408]}\end{array}$ & $\begin{array}{l}-0.2046 \\
{[0.1459]}\end{array}$ & $\begin{array}{l}0.4372^{*} \\
{[0.2485]}\end{array}$ \\
\hline Secondary(1=Yes) & $\begin{array}{c}0.4980^{*} \\
{[0.1616]}\end{array}$ & $\begin{array}{c}-0.4904^{*} \\
{[0.1616]}\end{array}$ & $\begin{array}{l}-0.2462 \\
{[0.2752]}\end{array}$ & $\begin{array}{l}-0.3120 \\
{[0.2862]}\end{array}$ & $\begin{array}{l}0.8861^{\circ} \\
{[0.4939]}\end{array}$ \\
\hline Degree(1=Yes) & $\begin{array}{l}0.6538 * * \\
{[0.2967]}\end{array}$ & $\begin{array}{c}-0.6431^{* *} \\
{[0.2967]}\end{array}$ & $\begin{array}{l}-0.1025 \\
{[0.5066]}\end{array}$ & $\begin{array}{l}-0.2068 \\
{[0.5273]}\end{array}$ & $\begin{array}{l}1.7127^{*} \\
{[0.9024]}\end{array}$ \\
\hline Married & $\begin{array}{c}0.0180 \\
{[0.0313]}\end{array}$ & $\begin{array}{l}-0.0196 \\
{[0.0313]}\end{array}$ & $\begin{array}{c}0.0090 \\
{[0.0506]}\end{array}$ & $\begin{array}{c}0.0236 \\
{[0.0518]}\end{array}$ & $\begin{array}{c}0.0332 \\
{[0.0868]}\end{array}$ \\
\hline Number Children 0-3 & $\begin{array}{c}0.0273 \\
{[0.0460]}\end{array}$ & $\begin{array}{c}-0.0264 \\
{[0.0460]}\end{array}$ & $\begin{array}{c}0.0032 \\
{[0.0916]}\end{array}$ & $\begin{array}{l}-0.0284 \\
{[0.0977]}\end{array}$ & $\begin{array}{c}0.1850 \\
{[0.1512]}\end{array}$ \\
\hline Number Children 4-5 & $\begin{array}{l}-0.0391 \\
{[0.0499]}\end{array}$ & $\begin{array}{c}0.0398 \\
{[0.0499]}\end{array}$ & $\begin{array}{c}0.0335 \\
{[0.0934]}\end{array}$ & $\begin{array}{c}0.0575 \\
{[0.0937]}\end{array}$ & $\begin{array}{c}0.0308 \\
{[0.1907]}\end{array}$ \\
\hline Number Children 6-13 & $\begin{array}{l}-0.0043 \\
{[0.0278]}\end{array}$ & $\begin{array}{c}0.0045 \\
{[0.0278]}\end{array}$ & $\begin{array}{l}-0.0313 \\
{[0.0494]}\end{array}$ & $\begin{array}{l}-0.0283 \\
{[0.0506]}\end{array}$ & $\begin{array}{l}-0.0085 \\
{[0.0934]}\end{array}$ \\
\hline Pension Wealth & $\begin{array}{c}0.0124 \\
{[0.0104]}\end{array}$ & $\begin{array}{l}-0.0129 \\
{[0.0104]}\end{array}$ & $\begin{array}{l}-0.0070 \\
{[0.0177]}\end{array}$ & $\begin{array}{l}-0.0046 \\
{[0.0184]}\end{array}$ & $\begin{array}{l}-0.0287 \\
{[0.0312]}\end{array}$ \\
\hline Pension Wealth ${ }^{*}$ Age & $\begin{array}{l}-0.0002 \\
{[0.0002]}\end{array}$ & $\begin{array}{c}0.0002 \\
{[0.0002]}\end{array}$ & $\begin{array}{l}-0.0001 \\
{[0.0004]}\end{array}$ & $\begin{array}{l}-0.0000 \\
{[0.0004]}\end{array}$ & $\begin{array}{l}-0.0013^{*} \\
{[0.0007]}\end{array}$ \\
\hline Observations & 8,333 & 8,333 & 8,333 & 8,333 & 8,333 \\
\hline
\end{tabular}

Standard errors in brackets ${ }^{* * *} p<0.01,{ }^{* *} p<0.05,{ }^{*} p<0.1$, Pension Wealth variable is intrumented by dummes time and groups. Pension Wealth and Accrual Rate is measured in Ch\$100000.

Table 22: Impacts of the reform in subjective health - Women 


\title{
Mental Health
}

Subjective Well being - Control Function Approach - Men

(8)

(9)

(10)

(11)

(12)

(13)

(14)

VARIABLES

Feeling that

Feeling depressed all you do is

Having Feeling

an effort

happy

Felling alone Enjoys life Felling sad Feeling tired

Has lots of

Ase -100

Age2

Primary (1=Yes)

Secondary(1=Yes)

Degree(1=Yes)

\section{Married}

Number Children 0-3

Number Children 4-5

Number Children 6-13

\section{$-0.0263$}

[0.0659]

0.0007

[0.0007]

0.0994

[0.1510]

0.4017

[0.2792]

0.6664

[0.5022]

0.1918

[0.1846]

0.0739

[0.1313]

$-0.1007$

[0.0903]

0.0400

[0.0564]

0.0052

[0.0154]

$-0.0010^{* *}$

Pension Wealth"Age

Observations

\begin{abstract}
2,087
\end{abstract}

\subsection{4}

[0.0654]

$-0.0001$

[0.0007]

$-0.0128$

[0.1495]

0.2265

[0.2769]

0.3775

[0.4989]

0.2348

[0.1828]

0.0355

[0.1310]

$-0.1010$

[0.0891]

0.0673

[0.0558]

0.0083

[0.0153]

$-0.0010 * *$

[0.0004]

0.0742

$-0.1624^{*}$

[0.0656]

$-0.0006$

[0.0871]

0.0015

0.0110

[0.0007]

[0.0009]

[0.0678]

$-0.1501$

0.0552

0.0000

[0.0007]

[0.1972]

[0.1552]

$-0.2772$

$-0.0820$

0.1855

[0.2775]

$-0.3823$

0.0354

[0.2874]

[0.5010]

$-0.2011$

[0.6639]

$\begin{array}{lll}-0.2011 & 0.2884 & -0.3653^{\circ} \\ {[0.1836]} & {[0.2457]} & {[0.1899]}\end{array}$

0.2345

$-0.3653^{\circ}$

0.0049

$[0.2457]$
0.1984

$0.1899]$
-0.0187

[0.1947] [0.1368]

[0.1311]

$-0.1308$

$-0.0770$

$-0.0602$

[0.0886]

[0.1124]

$[0.0557]$

0.0275

[0.0940]

$-0.0007$

[0.0738]

$0.0311^{*}$

[0.0159]

$-0.0342$

[0.0218]

[0.0582]

0.0026

$-0.0004$

[0.0004]

$0.0010^{*}$

[0.0006]

[0.0161]

$-0.0005$

[0.0004]

\begin{abstract}
2,087
\end{abstract}
2,087

2,087

2,087

0.0133

0.0133

$-0.0005$

$-0.0516$

[0.0648]

$\begin{array}{ccc}{[0.0648]} & {[0.0653]} & {[0.0653]} \\ 0.0009 & 0.0002 & -0.0005\end{array}$

$-0.0106$

$\left[\begin{array}{llll}{[0.0008} & {[0.0007]} & {[0.0007]} & {[0.0007]}\end{array}\right.$

$\begin{array}{llll}0.0712 & 0.3353^{* *} & -0.1299 & 0.1452\end{array}$

$\begin{array}{llll}{[0.1753]} & {[0.1485]} & {[0.1500]} & {[0.1504]}\end{array}$

$\begin{array}{llll}0.2002 & 0.7486^{* * *} & -0.1915 & 0.1689\end{array}$

$[0.3301] \quad[0.2742] \quad[0.2750] \quad[0.2792]$

$\begin{array}{llll}0.5807 & 1.2615^{* *} & -0.4535 & 0.3924\end{array}$

$\left[\begin{array}{llll} & 0.5987] & {[0.4943]} & {[0.4938]}\end{array}\right][0.5037]$

$\begin{array}{llll}0.2891 & 0.3407^{*} & -0.1628 & 0.2167\end{array}$

$[0.2187] \quad[0.1806] \quad[0.1813] \quad[0.1844]$

$\begin{array}{lllll}-0.0009 & -0.0502 & 0.0488 & 0.0496\end{array}$

$[0.1470] \quad[0.1286] \quad[0.1330] \quad[0.1325]$

$\begin{array}{llll}-0.1017 & -0.0649 & -0.1085 & -0.0476\end{array}$

$\left[\begin{array}{llll}{[0.0968]} & {[0.0868]} & {[0.0882}\end{array}\right][0.0880]$

$\begin{array}{lllll}0.0530 & 0.0826 & 0.0095 & 0.0454\end{array}$

$\left[\begin{array}{llll}{[0.0649]} & {[0.0551]} & {[0.0556]} & {[0.0560]}\end{array}\right.$

$\begin{array}{llll}-0.0204 & -0.0031 & 0.0309^{* *} & -0.0061\end{array}$

$\left[\begin{array}{llll}{[0.0192]} & {[0.0153]} & {[0.0147]} & {[0.0158]}\end{array}\right.$

$\begin{array}{llll}0.0000 & -0.0014^{* * *} & -0.0001 & -0.0003\end{array}$

$[0.0005] \quad[0.0004] \quad[0.0004] \quad[0.0004]$

Standard errors in brackets ${ }^{* * *} \mathrm{p}<0.01,{ }^{* *} \mathrm{p}<0.05,{ }^{*} \mathrm{p}<0.1$, Pension Wealth variable is intrumented by dummes time and groups. Pension Wealth and Accrual Rate is measured in Ch\$100000.

Table 23: Impacts of the reform in mental health - Men 
Subjective Well being - Control Function Approach - Women
(6)
(7)
(8)
(9) (10)
(11)
(12)
(13)
(14)

VARIABLES

Feeling depressed all you do is

Having Feeling

Felling alone Enjoys life Felling sad Feeling tired

Has lots of an effort restless sleep happy energy

\begin{tabular}{|c|c|c|c|c|c|c|c|c|c|}
\hline Age & $\begin{array}{c}0.0692 \\
{[0.0757]}\end{array}$ & $\begin{array}{c}0.0727 \\
{[0.0753]}\end{array}$ & $\begin{array}{c}0.0794 \\
{[0.0751]}\end{array}$ & $\begin{array}{c}-0.1412 \\
{[0.0939]}\end{array}$ & $\begin{array}{c}0.0505 \\
{[0.0757]}\end{array}$ & $\begin{array}{c}-0.1100 \\
{[0.0814]}\end{array}$ & $\begin{array}{c}0.0286 \\
{[0.0781]}\end{array}$ & $\begin{array}{c}-0.0652 \\
{[0.0839]}\end{array}$ & $\begin{array}{r}-0.0110 \\
{[0.0746]}\end{array}$ \\
\hline Age2 & $\begin{array}{l}-0.0007 \\
{[0.0008]}\end{array}$ & $\begin{array}{r}-0.0006 \\
{[0.0008]}\end{array}$ & $\begin{array}{l}-0.0005 \\
{[0.0008]}\end{array}$ & $\begin{array}{c}0.0013 \\
{[0.0009]}\end{array}$ & $\begin{array}{l}-0.0006 \\
{[0.0008]}\end{array}$ & $\begin{array}{c}0.0008 \\
{[0.0008]}\end{array}$ & $\begin{array}{c}-0.0004 \\
{[0.0008]}\end{array}$ & $\begin{array}{c}0.0007 \\
{[0.0009]}\end{array}$ & $\begin{array}{r}0.0001 \\
{[0.0008]}\end{array}$ \\
\hline Primary (1=Yes) & $\begin{array}{l}-0.1909 \\
{[0.1802]}\end{array}$ & $\begin{array}{r}-0.2076 \\
{[0.1786]}\end{array}$ & $\begin{array}{c}0.0245 \\
{[0.1791]}\end{array}$ & $\begin{array}{c}0.0355 \\
{[0.2248]}\end{array}$ & $\begin{array}{c}-0.1996 \\
{[0.1791]}\end{array}$ & $\begin{array}{c}0.0571 \\
{[0.1939]}\end{array}$ & $\begin{array}{c}0.0557 \\
{[0.1885]}\end{array}$ & $\begin{array}{c}-0.1564 \\
{[0.2038]}\end{array}$ & $\begin{array}{r}-0.0871 \\
{[0.1776]}\end{array}$ \\
\hline Secondary(1=Yes) & $\begin{array}{c}-0.4161 \\
{[0.3280]}\end{array}$ & $\begin{array}{c}-0.4492 \\
{[0.3270]}\end{array}$ & $\begin{array}{c}-0.1432 \\
{[0.3282]}\end{array}$ & $\begin{array}{c}-0.0279 \\
{[0.4291]}\end{array}$ & $\begin{array}{c}-0.3232 \\
{[0.3280]}\end{array}$ & $\begin{array}{c}0.1207 \\
{[0.3632]}\end{array}$ & $\begin{array}{l}-0.0340 \\
{[0.3440]}\end{array}$ & $\begin{array}{c}-0.2764 \\
{[0.3738]}\end{array}$ & $\begin{array}{r}-0.0836 \\
{[0.3254]}\end{array}$ \\
\hline Degree(1=Yes) & $\begin{array}{l}-0.6937 \\
{[0.5929]}\end{array}$ & $\begin{array}{c}-0.7965 \\
{[0.5931]}\end{array}$ & $\begin{array}{c}-0.1411 \\
{[0.5940]}\end{array}$ & $\begin{array}{c}0.1392 \\
{[0.7877]}\end{array}$ & $\begin{array}{c}-0.6840 \\
{[0.5949]}\end{array}$ & $\begin{array}{c}0.1475 \\
{[0.6608]}\end{array}$ & $\begin{array}{c}-0.0505 \\
{[0.6221]}\end{array}$ & $\begin{array}{l}-0.4736 \\
{[0.6757]}\end{array}$ & $\begin{array}{l}-0.1076 \\
{[0.5886]}\end{array}$ \\
\hline Married & $\begin{array}{c}-0.1431^{* *} \\
{[0.0623]}\end{array}$ & $\begin{array}{r}-0.0692 \\
{[0.0618]}\end{array}$ & $\begin{array}{c}-0.1402^{* *} \\
{[0.0619]}\end{array}$ & $\begin{array}{c}0.2801^{* * *} \\
{[0.0740]}\end{array}$ & $\begin{array}{c}-0.3097^{* * *} \\
{[0.0621]}\end{array}$ & $\begin{array}{c}0.2028^{* * *} \\
{[0.0655]}\end{array}$ & $\begin{array}{l}-0.0475 \\
{[0.0650]}\end{array}$ & $\begin{array}{c}0.0055 \\
{[0.0682]}\end{array}$ & $\begin{array}{r}0.0035 \\
{[0.0615]}\end{array}$ \\
\hline Number Children 0-3 & $\begin{array}{l}0.2373^{*} \\
{[0.1299]}\end{array}$ & $\begin{array}{l}-0.1032 \\
{[0.1277]}\end{array}$ & $\begin{array}{c}0.0240 \\
{[0.1270]}\end{array}$ & $\begin{array}{l}-0.1039 \\
{[0.1514]}\end{array}$ & $\begin{array}{l}-0.0052 \\
{[0.1276]}\end{array}$ & $\begin{array}{l}-0.1015 \\
{[0.1331]}\end{array}$ & $\begin{array}{c}0.0715 \\
{[0.1323]}\end{array}$ & $\begin{array}{l}-0.1042 \\
{[0.1356]}\end{array}$ & $\begin{array}{r}0.0686 \\
{[0.1265]}\end{array}$ \\
\hline Number Children 4-5 & $\begin{array}{l}-0.0149 \\
{[0.0908]}\end{array}$ & $\begin{array}{l}-0.0961 \\
{[0.0897]}\end{array}$ & $\begin{array}{l}-0.0266 \\
{[0.0888]}\end{array}$ & $\begin{array}{l}-0.0892 \\
{[0.1083]}\end{array}$ & $\begin{array}{l}-0.1101 \\
{[0.0896]}\end{array}$ & $\begin{array}{c}0.0709 \\
{[0.0976]}\end{array}$ & $\begin{array}{l}-0.0507 \\
{[0.0923]}\end{array}$ & $\begin{array}{l}-0.0227 \\
{[0.0976]}\end{array}$ & $\begin{array}{r}-0.0776 \\
{[0.0892]}\end{array}$ \\
\hline Number Children 6-13 & $\begin{array}{c}0.1271^{* *} \\
{[0.0550]}\end{array}$ & $\begin{array}{c}0.1032^{*} \\
{[0.0546]}\end{array}$ & $\begin{array}{c}0.1166^{* *} \\
{[0.0546]}\end{array}$ & $\begin{array}{c}-0.0531 \\
{[0.0689]}\end{array}$ & $\begin{array}{c}0.0392 \\
{[0.0551]}\end{array}$ & $\begin{array}{c}-0.0787 \\
{[0.0591]}\end{array}$ & $\begin{array}{l}0.1029^{*} \\
{[0.0572]}\end{array}$ & $\begin{array}{c}0.0437 \\
{[0.0614]}\end{array}$ & $\begin{array}{l}-0.0538 \\
{[0.0543]}\end{array}$ \\
\hline Pension Wealth & $\begin{array}{c}0.0061 \\
{[0.0197]}\end{array}$ & $\begin{array}{c}0.0189 \\
{[0.0198]}\end{array}$ & $\begin{array}{c}0.0248 \\
{[0.0198]}\end{array}$ & $\begin{array}{c}0.0134 \\
{[0.0284]}\end{array}$ & $\begin{array}{c}0.0094 \\
{[0.0200]}\end{array}$ & $\begin{array}{c}-0.0072 \\
{[0.0232]}\end{array}$ & $\begin{array}{l}-0.0096 \\
{[0.0212]}\end{array}$ & $\begin{array}{c}0.0031 \\
{[0.0240]}\end{array}$ & $\begin{array}{r}-0.0029 \\
{[0.0198]}\end{array}$ \\
\hline Pension Wealth"Age & $\begin{array}{c}-0.0000 \\
{[0.0005]}\end{array}$ & $\begin{array}{c}-0.0003 \\
{[0.0005]}\end{array}$ & $\begin{array}{c}-0.0008 \\
{[0.0005]}\end{array}$ & $\begin{array}{c}0.0001 \\
{[0.0006]}\end{array}$ & $\begin{array}{c}-0.0001 \\
{[0.0005]}\end{array}$ & $\begin{array}{c}0.0004 \\
{[0.0006]}\end{array}$ & $\begin{array}{c}-0.0002 \\
{[0.0005]}\end{array}$ & $\begin{array}{c}0.0003 \\
{[0.0006]}\end{array}$ & $\begin{array}{r}0.0001 \\
{[0.0005}\end{array}$ \\
\hline Observations & 1,959 & 1,959 & 1,959 & 1,959 & 1,959 & 1,959 & 1,959 & 1,959 & 1,959 \\
\hline
\end{tabular}

Standard errors in brackets ${ }^{* * *}$ p $<0.01, \cdots * 0.05, * p<0.1$, Pension Wealth variable is intrumented by dummes time and groups. Pension Wealth and Accrual Rate is measured in Ch\$100000.

Table 24: Impacts of the reform in mental health - Women 


\section{Self-reported life expectancy}

\begin{tabular}{|c|c|c|}
\hline \multicolumn{3}{|c|}{ Life Expectancy - Control Function Approach - Men } \\
\hline VARIABLES & $\begin{array}{c}\text { (1) } \\
\text { Life Expectancy } \\
65 \text { Years Old }\end{array}$ & $\begin{array}{c}\text { (2) } \\
\text { Life Expectancy } \\
75 \text { Years Old }\end{array}$ \\
\hline \multirow[t]{2}{*}{ Age } & -0.1454 & -0.1454 \\
\hline & {$[0.4022]$} & {$[0.4022]$} \\
\hline \multirow[t]{2}{*}{ Age2 } & 0.0016 & 0.0016 \\
\hline & {$[0.0048]$} & {$[0.0048]$} \\
\hline \multirow[t]{2}{*}{ Primary (1=Yes) } & 1.7577 & 1.7577 \\
\hline & [1.2264] & [1.2264] \\
\hline \multirow[t]{2}{*}{ Secondary(1=Yes) } & 2.8838 & 2.8838 \\
\hline & [2.2747] & [2.2747] \\
\hline \multirow[t]{2}{*}{ Degree(1=Yes) } & $7.4112^{*}$ & $7.4112^{*}$ \\
\hline & [4.1354] & [4.1354] \\
\hline \multirow[t]{2}{*}{ Married } & 2.2993 & 2.2993 \\
\hline & [1.5081] & [1.5081] \\
\hline \multirow[t]{2}{*}{ Number Children 0-3 } & 0.3706 & 0.3706 \\
\hline & {$[0.7404]$} & {$[0.7404]$} \\
\hline \multirow[t]{2}{*}{ Number Children 4-5 } & 0.1725 & 0.1725 \\
\hline & {$[0.8205]$} & {$[0.8205]$} \\
\hline \multirow[t]{2}{*}{ Number Children 6-13 } & 0.3953 & 0.3953 \\
\hline & {$[0.4805]$} & {$[0.4805]$} \\
\hline \multirow[t]{2}{*}{ Pension Wealth } & 0.0028 & 0.0028 \\
\hline & {$[0.1721]$} & {$[0.1721]$} \\
\hline \multirow[t]{2}{*}{ Pension Wealth*Age } & -0.0005 & -0.0005 \\
\hline & [0.0033] & [0.0033] \\
\hline Observations & 9,012 & 9,012 \\
\hline \multicolumn{3}{|c|}{$\begin{array}{l}\text { Standard errors in brackets }{ }^{* * *} p<0.01,{ }^{* *} p<0.05,{ }^{*} p<0.1 \text {, } \\
\text { Pension Wealth variable is intrumented by dummes time and } \\
\text { groups. Pension Wealth and Accrual Rate is measured in } \\
\text { Ch\$100000. }\end{array}$} \\
\hline
\end{tabular}

Table 25: Impacts of the reform in self-reported life expectancy - Men 
Life Expectancy - Control Function Approach - Women

(1)

(2)

\begin{tabular}{|c|c|c|}
\hline VARIABLES & $\begin{array}{l}\text { Life Expectancy } \\
65 \text { Years Old }\end{array}$ & $\begin{array}{c}\text { Life Expectancy } \\
75 \text { Years Old }\end{array}$ \\
\hline Age & $\begin{array}{c}-0.9548^{* *} \\
{[0.4364]}\end{array}$ & $\begin{array}{c}-0.9548^{* *} \\
{[0.4364]}\end{array}$ \\
\hline Age2 & $\begin{array}{l}0.0096^{*} \\
{[0.0053]}\end{array}$ & $\begin{array}{l}0.0096^{*} \\
{[0.0053]}\end{array}$ \\
\hline Primary (1=Yes) & $\begin{array}{c}0.1729 \\
{[1.5857]}\end{array}$ & $\begin{array}{c}0.1729 \\
{[1.5857]}\end{array}$ \\
\hline Secondary(1=Yes) & $\begin{array}{c}0.5125 \\
{[2.9227]}\end{array}$ & $\begin{array}{c}0.5125 \\
{[2.9227]}\end{array}$ \\
\hline Degree(1=Yes) & $\begin{array}{c}0.3746 \\
{[5.3184]}\end{array}$ & $\begin{array}{c}0.3746 \\
{[5.3184]}\end{array}$ \\
\hline Married & $\begin{array}{c}0.5228 \\
{[0.5761]}\end{array}$ & $\begin{array}{c}0.5228 \\
{[0.5761]}\end{array}$ \\
\hline Number Children 0-3 & $\begin{array}{c}1.2464 \\
{[0.8003]}\end{array}$ & $\begin{array}{c}1.2464 \\
{[0.8003]}\end{array}$ \\
\hline Number Children 4-5 & $\begin{array}{c}-2.3129^{* * *} \\
{[0.8829]}\end{array}$ & $\begin{array}{c}-2.3129^{* * *} \\
{[0.8829]}\end{array}$ \\
\hline Number Children 6-13 & $\begin{array}{l}-0.5677 \\
{[0.5046]}\end{array}$ & $\begin{array}{c}-0.5677 \\
{[0.5046]}\end{array}$ \\
\hline Pension Wealth & $\begin{array}{c}0.1091 \\
{[0.1861]}\end{array}$ & $\begin{array}{c}0.1091 \\
{[0.1861]}\end{array}$ \\
\hline Pension Wealth*Age & $\begin{array}{c}0.0050 \\
{[0.0041]}\end{array}$ & $\begin{array}{c}0.0050 \\
{[0.0041]}\end{array}$ \\
\hline Observations & 8,282 & 8,282 \\
\hline $\begin{array}{l}\text { Standard errors in bracl } \\
\text { Pension Wealth variable } \\
\text { groups. Pension Wealth } \\
\text { Ch } \$ 100000 \text {. }\end{array}$ & $\begin{array}{l}* * \mathrm{p}<0.01, * * \\
\text { trumented by } \\
\text { Accrual Rate is }\end{array}$ & $\begin{array}{l}0.05,{ }^{*} p<0.1 \\
\text { mmes time and } \\
\text { heasured in }\end{array}$ \\
\hline
\end{tabular}

Table 26: Impacts of the reform in self-reported life expectancy - Women 